\title{
Earnings Management, Capital Structure, and the Role of Institutional Environments *
}

\author{
Zhe An† Donghui Li \\ School of Banking and Finance \\ Australian School of Business \\ University of New South Wales, Australia
}

January 15, 2013

\begin{abstract}
This paper examines the effect of earnings management on financial leverage and how this relation is influenced by institutional environments by employing a large panel of 25,798 firms across 37 countries spanning the years 1989 to 2009 . We find that firms with high earnings management activities tend to have high corporate leverage. More importantly, this positive relation is attenuated by strong institutional environments. Our results lend strong support to the agency theory of free cash flow. Various robustness tests confirm our main conclusions.
\end{abstract}

JEL Classifications: G32, G15.

Keywords : Earnings management, agency conflicts, empirical capital structure, institutional environments.

\footnotetext{
*All errors are our responsibility

†Email: zhe.an@unsw.edu.au

‡Email: donghui@unsw.edu.au

${ }^{\S}$ Email: jin.yu@unsw.edu.au
} 


\section{Introduction}

Although many empirical studies have endeavored to use firm and industry characteristics to explain the variation of corporate leverage 1 there is growing research that highlights the important role of institutional environments in determining capital structure decisions. These latter studies find that strong institutional environments tend to decrease financial leverage $2^{2}$ This evidence is consistent with the findings that strong investor protection and legal enforcement mitigate agency conflicts and lead to high corporate valuation (see, e.g., La Porta, Lopez-de-Silanes, Shleifer, and Vishny (1998) and La Porta, Lopez-De-Silanes, Shleifer, and Vishny (2002)).

On the other hand, corporate debt, similar to institutional environments, may serve as an external control mechanism in reducing agency conflicts (see, e.g., Jensen (1986) and Jensen and Meckling (1976)). However, the costs of institutional environments and corporate debt in mitigating agency conflicts are different. Relying on institutional environments in mitigating agency conflicts does not carry incremental costs for individual firms, since institutional environments are broadly thought to be set beyond firms' control. Conversely, high leverage is associated with high expected bankruptcy costs and large agency costs of debt (i.e., debt overhang and asset substitution problems). We therefore presume the reliance on institutional environment is less costly than on corporate debt, and hypothesize that strong institutional environment reduce the demand for debt in mitigating agency conflicts. In this paper, we examine whether corporate leverage is positively correlated with agency conflicts and whether this positive relation is attenuated in countries with strong institutional environments.

We use earnings management as a proxy for agency conflicts between in-

\footnotetext{
${ }^{1}$ For example, Titman and Wessels (1988), Lemmon, Roberts, and Zender (2008), and Frank and Goyal (2009), study how U.S. firms' leverage variations are explained by firm and industry characteristics.

${ }^{2}$ For example, Demirguc-Kunt and Maksimovic (1998), Demirguc-Kunt and Maksimovic (1999), Booth, Aivazian, Demirguc-Kunt, and Maksimovic (2001), Giannetti (2003), Antoniou, Guney, and Paudyal (2008), and Fan, Titman, and Twite (2012) examine the associations between institutional environments and capital structure by employing multicountry data.
} 
siders and outside investors ${ }^{3}$ Managerial discretion/judgment in reported earnings may make firms' true underlying economic performance, e.g. operating cash flow, private information available only to insiders. Therefore, earnings management allows managers to finance sub-optimal investments that maximize their own utilities at the expense of some informationally disadvantaged stakeholders. Similarly, earnings management may facilitate insiders' tunneling activities.

Based on the agency cost of free cash flow theory, we study whether corporate leverage is higher for firms with more earnings management which exacerbates the information asymmetry of free cash flow $4^{4}$ Next, we examine how institutional environments influence the impact of earnings management on corporate leverage. We argue that strong institutional environments mitigating agency conflicts by granting investors rights in preventing managers from expropriating their investments and ensuring investors' rights can be implemented in the time of need. Thus, in order to reduce cost of debt financing, investors of firms operating in stronger institutional environments countries becomes more relying on "free" macro-level investor protection than using debt as a control mechanism. Therefore, we expect the earnings management - capital structure relation is less pronounced in the countries with strong institutional settings.

To empirically address these questions, we employ an international sample of 37 countries spanning the years 1989 to 2009 to investigate how corporate leverage choices are determined by the level of earnings management across countries. Our multi-country data sample also allows us to test how country-level characteristics can affect the relation between earnings management and capital structure decisions.

\footnotetext{
${ }^{3}$ Leuz, Nanda, and Wysocki (2003) suggest that strong institutional environments can attenuate the agency conflicts by reducing managers' earnings management activities. They argue that strong institutional settings, in particular, strong investor protection and legal enforcement limit managers' ability to acquire private control benefits, thus, reduce the likelihood in earnings management activities.

${ }^{4}$ In addition, the above prediction is also consistent with pecking order theory (See, e.g., Myers (1984) and Myers and Majluf (1984)). That is, earnings management increases firms' external financing costs, external equity financing becomes disproportionally less desirable than debt when external funding is needed for investment.
} 
Consistent with our hypotheses, we have two novel empirical findings. First, we show that earnings management is significantly and positively correlated with firms' leverage. Combined with the notion that a firm's earnings management reflects the agency conflicts of information asymmetry between managers and investors, this finding is consistent with the agency theory of free cash flow.

Second, we examine the role of institutional environments in shaping the relation between earnings management and capital structure decisions. We study this effect by adding an interaction term of earnings management and institutional environments to our model. We document that strong institutional environments tend to attenuate the positive relation between earnings management and corporate leverage. This evidence indicates that strong institutional environments grant and enforce investor rights in mitigating impact of earnings management on corporate decisions, which make earnings management less sensitive to capital structure decisions.

This paper contributes to the existing literature from the following aspects. First, earnings management is explicitly used to proxy information asymmetry of free cash flow in a large international sample, confirming its suitability documented by Leuz, Nanda, and Wysocki (2003). We provide novel evidence on the firm-level heterogeneity in corporate leverage that complements the extant capital structure literature (see, e.g., Titman and Wessels (1988), Lemmon, Roberts, and Zender (2008), and Frank and Goyal (2009)). In particular, we document the positive relation between earnings management and corporate leverage which is consistent with both free cash flow and pecking order theories.

Second, the role of institutional environments in shaping earnings management - corporate leverage sensitivity is documented. This broadens the existing literature on the impact of institutional environments on corporate leverage by documenting this impact is implemented by reducing the impact of earnings management on corporate leverage. This paper emphasizes the role of institutional environments that effectively reduces the impact of information asymmetry on capital structure decisions. Thus contributes to the existing international study on corporate leverage from a new angle. 
For example, Rajan and Zingales (1995), Demirguc-Kunt and Maksimovic (1998), Demirguc-Kunt and Maksimovic (1999), Demirguc-Kunt and Maksimovic (1999), Booth, Aivazian, Demirguc-Kunt, and Maksimovic (2001), Giannetti (2003), Antoniou, Guney, and Paudyal (2008), Fan, Titman, and Twite (2012) document that firms' capital structure choices are influenced by countries' institutional settings. In addition, Oztekin and Flannery (2012) find that transactions costs of external financing are lower and the speed of leverage adjustment is higher in countries with better institutional environments. Halling, Yu, and Zechner (2012) document that the speed of adjustments toward target corporate leverage decreases during recessions in an international sample containing 18 countries.

This paper is organized as follows. We discuss the theoretical motivation and empirical hypotheses in Section 2 and empirical design in Section 3 , Our data and sample are reported in Section 4 Sections 5 and 6 report the empirical results and robustness tests; Finally, Section 7 concludes the paper.

\section{Theoretical motivation and empirical hypothe- ses}

This section provides a summary of predictions on how earnings management as a proxy for information asymmetry affects corporate leverage, followed by a discussion on what the role of institutional environments is in shaping the earnings management - corporate leverage sensitivity.

\subsection{Earnings management in determining capital structure}

Our prior discussion in Section 1 explains that earnings management may encourage corporate insiders to engage in tunneling activities and/or suboptimal investment because it makes information about cash flow private to insiders. On the other hand, agency cost of free cash flow theory indicates that increasing borrowing can serves as an external control mechanism mitigating the free cash flow problem (see, e.g., Jensen (1986) and Jensen and 
Meckling (1976)). In particular, interests must be repaid to avoid default and to reduce the amount of free cash flow available to corporate managers. Controlling for deadweight costs of debt, such as bankruptcy costs and agency cost of debt, higher earnings management activities increase the demand for debt as an external control mechanism.

H1. Firms with higher level of earnings management are expected to have higher financial corporate leverage, ceteris paribus.

\subsection{The role of institutional environments}

Jensen (1993) argues that institutional environments, including legal, political, or regulatory system, is one of the effective external control mechanisms to resolve agency conflicts. In addition, La Porta, Lopez-de-Silanes, Shleifer, and Vishny (1998) document that capital markets are more developed in countries with more sophisticated legal systems. Capital markets competition, such as hostile takeover, is another external control mechanism that alleviates agency problem. Thus, institutional environments can mitigate the agency conflicts.

In addition, there are no incremental costs for individual firms to mitigate agency conflicts by relying on institutional environments, since institutional environments are broadly thought to be set beyond firms' control. In contrast, debt serves as an external control mechanism in reducing agency conflicts, is associated with expected bankruptcy costs and agency costs of debt. Therefore, in order to reduce cost of debt financing, investors of firms operating in countries with stronger institutional environments become more reliant on "cheaper" macro-level investor protection than using debt as a control mechanism.

In particular, we hypothesize that, in determining capital structure, strong institutional settings mitigate the agency conflicts by reducing its sensitivity to corporate leverage. That is, strong investor protection grants investors rights in preventing managers from expropriating their investments; and strong legal enforcement ensures investors' rights can be implemented 
in the time of need. Consequently, investors rely more on institutional environments and demand less debt in mitigating the free cash flow problem.

In this paper, we use six macro-level institutional environment variables which measure the level of legal origin (LegCom), enforcement (P_Enfor), shareholder protection $\left(P_{-} S H\right)$, accounting information quality $\left(P_{-} A c c t\right)$, governance $\left(P_{-} K 09\right)$, and ethics $\left(P_{-} K 04\right)$ of the country. We expect that the impact of earnings management on corporate leverage is lower in the countries with common law legal system, stronger legal enforcement, better shareholder protection and accounting information quality, higher governance and ethic indices. So, the second hypothesize is as follows.

H2. The positive association between earnings management and leverage ratio is attenuated in countries with strong institutional environments (IE), ceteris paribus.

\section{Empirical design}

\subsection{Empirical model}

Empirical capital structure research shows that leverage ratio is a function of various firm, industry and country characteristics. In this paper, we focus on the effect of earnings management on firms' capital structure decisions. Moreover, we examine how this relation is influenced by macro-level institutional environments.

Specifically, we regress realized actual leverage ratio on earnings management measure and on its interaction with macro-level institutional environment variable. Our empirical model is given as follows,

$$
\begin{aligned}
L_{j, i, t}= & \beta_{0}+\beta_{1} E M_{j, i, t-1}+\beta_{2} E M_{j, i, t-1} \times I E_{j}+\gamma \mathbf{X}_{j, i, t-1} \\
& +\boldsymbol{\delta} \mathbf{X}_{j, i, t-1} \times I E_{j}+\boldsymbol{\lambda} \mathbf{Y}_{j, t-1}+f_{i}+y_{t}+e_{j, i, t},
\end{aligned}
$$

where country is indexed by $j$, firm by $i$, and time by $t$. We use either market leverage ratio $(M L)$ or book leverage ratio $(B L)$ as dependent variable (i.e. $L \in\{M L, B L\})$. $E M$ is our earnings management variable. 
Macro-level institutional environment variable is denoted by $I E . \mathbf{X}_{j, i, t}$ is a vector of firm and industry control variables, including Tangibility (Tang), Firm Size (Size), Profitability (Prof), Market to Book ratio (MTB) and Industry Median Leverage (IndMed). $\mathbf{Y}_{j, t}$ is a vector of country control variables, including GDP per capita $(G D P C)$, Stock Market Capitalization to GDP $(M C A P)$ and GDP Growth $(G G D P)$. In order to capture the unobserved heterogeneity across firm and time, we control for firm fixed effects $f_{i}$ and year fixed effects $y_{t}$ in equation (1) 5 Standard errors are robust to clustering within each country.

\subsection{Earnings management measures}

Healy and Wahlen (1999) define earnings management as

"Earnings management occurs when managers use judgment in financial reporting and in structuring transactions to alter financial reports to either mislead some stakeholders about the underlying economic performance of the company, or to influence contractual outcomes that depend on reported accounting numbers"(p.6).

Conflict of interest exists between inside managers and outside investors in a corporate context. Managers have incentives to use their control to extract private benefits at expense of other stakeholders. Outsiders monitor managers' behavior and take discipline actions if such extractions are detected. Thus, managers also have incentives to mask their private control benefits from outsiders by reducing the variability of reported earnings. For example, in years of good performance, managers use financial reporting accruals to understate earnings which creates reserves for the years of bad performance. It smoothens financial earnings and hides managers' private control benefits, in consequence, creates information asymmetry about free cash flow between insiders and outsiders. Therefore, managerial discretion

\footnotetext{
${ }^{5}$ Time-invariant measures have no explanatory power in a firm-fixed effects framework, so we do not include $I E$ variable itself in the model (see, e.g., Mclean, Zhang, and Zhao (2012), p.317).
} 
and/or smoothing activities in financial earnings can lead to information asymmetry about cash flow between inside managers and outside existing and/or potential investors.

In this paper, we use earnings management as a proxy for information asymmetry of free cash flow. Our earnings management measures are based on Leuz, Nanda, and Wysocki (2003) that develop several variables that capture various dimensions along which insiders can exercise discretion in reporting earnings and reduce variability of reported earnings by altering accounting accruals.

Our first earnings management variable is earnings discretion $(A c c r)$. It captures the extent that insiders can exercise discretion in reporting earnings. Leuz, Nanda, and Wysocki (2003) define the magnitude of accruals as the absolute value of firms' accruals scaled by the absolute value of firms' cash flow from operations. Dechow, Sloan, and Sweeney (1996) argue that accruals increase as the alleged year of earnings manipulation approaches, and then experience a sharp decline. The increase in accruals is consistent with managerial manipulation. The following decline is consistent with the reversal of prior accrual overstatements. In addition, Dechow, Sloan, and Sweeney (1996) also suggest that it usually takes several years to detect managerial manipulation. Thus, our Accr is computed as the 5 year moving average of the magnitude of accruals. 6

Our second (Smth) and third (Corr) earnings management variables capture earnings smoothing. In particular, Smth measures the extent that insiders reduce the variability of reported earnings by altering accounting accruals. It is computed as the standard deviation of firms' operating income scaled by the standard deviation of firms' cash flow from operations.7 Corr captures the extent that insiders conceal economic shocks to firms'

\footnotetext{
${ }^{6}$ Accr $_{j, i, t}=1 / 5 \sum_{t}^{t+4} \mid$ Accrual $_{j, i, t} / C F_{j, i, t} \mid$, Accruals $=(\Delta$ Assets $-\Delta$ Cash and equivalent $)-(\Delta$ Current liability $-\Delta$ Short term debt $-\Delta$ Income taxes payable $)-$ Depreciation and amortization expense, Cash flow from operations $(C F)=$ Operating income-Accruals. When short-term debt and taxes payable are not available for a firm, then their changes are assumed zero. All accounting variables are scaled by lagged total assets. A minimum of 3 years is required.

${ }^{7}$ Smth $=-\sigma$ (Operating income $) / \sigma(C F)$ over the last 5 years. A minimum of 3 years is required.
} 
operating cash flow by using their accounting discretion. It is computed as the correlation between changes in accruals and changes in cash flow from operations 89 We multiply Smth and Corr by -1 . In such a way, higher values of Accr, Smth, and Corr imply higher level of earnings management of the firms. Finally, the first principle component of Accr, Smth, and Corr $\left(P_{-} E M\right)$ is used as an aggregate measure of earnings management.

\subsection{Proxies for institutional environments}

In order to study how institutional environments affect the impact of earnings management on firms' capital structure decisions, we firstly draw several macro-level variables from La Porta, Lopez-de-Silanes, Shleifer, and Vishny (1998), covering different aspects of institutional environments. In particular, La Porta, Lopez-de-Silanes, Shleifer, and Vishny (1998) suggest that countries with legal systems based on common law provide better investor protection than civil law countries. We use the English common law dummy $(\mathrm{LegCom})$ as a measure of investor protection. It equals 1 if the country's legal system is based on common law, and 0 otherwise. In addition, strong legal enforcement ensures investors' rights can be implemented at the time of need and protects their investments from managers' expropriation. As a consequence, we also examine an enforcement variable ( $P_{-}$Enfor $)$which is the first principle of the following five legal enforcement proxies: efficiency of judicial system (RulLaw), rule of law (EffJud), level of corruption (Corruption), risk of expropriation (RisExp), and repudiation of contracts by government (Repudiation).

In robustness section, we examine a number of alternative macro-level institutional environment measures. In particular, we use macro-level variables that measure shareholder rights $\left(P_{-} S H\right)$ and accounting information quality $\left(P_{-} A c c t\right)$. $P_{-} S H$ is the first principle component of anti-director in$\operatorname{dex}(A n t i D)$ and anti-self-dealing index (AntiSelf); and $P_{-}$Acct is the first

\footnotetext{
${ }^{8}$ Corr $=-\rho(\triangle A c c r, \triangle C F)$ over the last 5 years. A minimum of 3 years is required.

${ }^{9}$ In the robustness tests, we recalculate Accr, Smth and Corr by restricting the data has to be available at least 3 out of the last 4 (6) years. The results are qualitatively consistent.
} 
principle component of accounting standards (AccStd90) and auditing practices (Audit).

In addition, as alternatives to institutional environments, we also use the Worldwide Governance Indicators ( WGI) developed by Kaufmann, Kraay, and Mastruzzi (2009). They define WGI as a series of indicators that measure "the traditions and institutions by which authority in a country is exercised". This includes six broad aspects of governance: accountability, political instability, government effectiveness, regulatory burden, rule of law, and control of corruption. 10 We compute the first principal component of these six WGIs and denote this variable by $P_{-}$K09. In addition, Kaufmann (2004) develops six ethics indices that cover various dimensions of corporate and public sector ethics and governance. These indices include corporate illegal corruption component, corporate legal corruption component, corporate ethics index, public sector ethics index, judicial/legal effectiveness index, and corporate governance index. We compute the first principal component of these six ethics indices and use it as a single ethics index. This variable is denoted by $P_{-} K 04$. In order to avoid possible muticollinearity between the macro-level $I E$ variables, we use one $I E$ variable in one regression.

\section{Data and sample}

We collect firm-level accounting data from Worldscope which contains annual financial data of publicly traded firms around the world. We extract macro-level institutional environment variables from La Porta, Lopez-deSilanes, Shleifer, and Vishny (1998), Djankov, La Porta, Lopez-de-Silanes, and Shleifer (2008), Bushman, Piotroski, and Smith (2004), Kaufmann, Kraay, and Mastruzzi (2009), and Kaufmann (2004). Country-level control variables ( $G D P C, M C A P$ and $G G D P$ ) are obtained from World development indicators (WDI) 11

\footnotetext{
${ }^{10}$ The six Worldwide Governance Indicators ( WGI) cover 212 countries and territories for the years of 1996, 1998, 2000, and annually for 2002 to 2009. We obtain the crosssectional $W G I s$ by taking the time-series mean of each WGI.

${ }^{11}$ The data of Taiwan is collected from the websites of National Statistic of Taiwan and Taiwan Stock Exchange.
} 
We apply several filters to remove potential data errors and outliers. Observations with leverage ratios beyond the unit interval are removed. The firm level variables are winsorized at $1 \%$ and $99 \%$ level. Following Leuz, Nanda, and Wysocki (2003), we remove the countries with less than 300 firm-year observations, and observations of Argentina, Brazil and Mexico are excluded from our sample since these countries experienced hyperinflation over the sample period. In addition, we remove financial or utility firms from the sample since their capital structures are presumably regulated and hence different from capital structures of firms in other industries. Firmyear observations with missing financial data are excluded from our sample. Finally, there are 166,325 firm-year observations left in the sample that contains 25, 798 firms across 37 countries spanning from 1989 to 2009.12

Table 1 provides a sample description that reports the number of years, firms and firm-years of each country. As shown in column 1, there are 24 out of 37 countries cover the full sample period (21 years). Column 3 reports the number of firm-year observations for each country in our sample. It shows that the data coverage of the sample is fairly different across countries. In general, developed countries tend to have better coverage than developing countries.

\section{[Insert Table 1]}

Table 2 report the summary statistics of our key firm, industry (Panel A), and country (Panel B) variables of interest. In general, our key dependent variables and explanatory variables resemble those used in the literature. In particular, the means (standard deviations) of market and book leverage ratios are $0.27(0.25)$ and $0.23(0.19)$, respectively.

[Insert Table 2]

For the earnings management variables, the sample means (standard deviations) of Accr, Smth, Corr and P_EM are 1.20(1.84), -0.66(0.42),

\footnotetext{
${ }^{12}$ The sample period starts from 1989 since some accounting data are not available prior to 1989 in Worldscope.
} 
$0.77(0.34)$ and $0.03(1.22)$, respectively. Table 3 reports the country medians for each earnings management variables. These moments are similar to those reported in Leuz, Nanda, and Wysocki (2003), though they focus on a 31-country sample.

[Insert Table 3

Panel C of Table 2 describes the statistics of macro-level institutional environment variables. Our institutional environment variables are available in most of the sample countries. In particular, $P_{-} K 09$ and $P_{-} K 04$ are available in all 37 countries. The rest of institutional environment variables are available in between 32 to 35 countries.

We present in Table 4 the correlation matrix between leverage ratios and firm and industry characteristics. This table shows how leverage ratios are correlated with firm and industry characteristics. Specifically, Table 4 exhibits that leverage ratios are positively associated with Accr, Smth, Corr, P_EM, Tang, Size, and IndMed, but negatively related to Prof and $M T B$. On the other hand, there is no evidence that independent variables are highly correlated.

[Insert Table 4]

\section{$5 \quad$ Empirical results}

This section presents regressions that estimate the influence of earnings management on capital structure decisions and how this relation is affected by institutional environments.

Firstly, we regress corporate leverage ratios on earnings management measures (Accr, Smth, Corr and P_EM) to examine how firms' earnings management activities affect their capital structure decisions. The results of market (book) leverage are reported in columns 1 to 4 (5 to 8) of Table 5. Columns 1 to 4 show that the coefficient estimates of our earnings management variables are all significantly positively related to market leverage. Specifically, the coefficient estimates (t-statistics) of Accr, 
Smth, Corr and P_EM are 0.1692(5.3464), 0.4193(3.8577), 0.3572(2.6882) and $0.1584(3.6077)$, respectively. These results are not only statistically but economically significant. For example, Table 2 shows that the standard deviation of $P_{-} E M$ is 1.22 . Multiplying it with the coefficient estimate of $P_{-} E M$ in column 4, 0.1584, our results indicate that one standard deviation increase in $P_{-} E M$ leads to about $0.1932 \%(=1.22 \times 0.1584 \%)$ increase in market leverage. 13 Moreover, given that the average market leverage in our sample is about 0.27 , a $0.1932 \%$ increase accounts for an about $0.72 \%$ $(=0.1932 \% / 0.27)$ change of market leverage for an average firm in our sample.

Columns 5 to 8 show that the results are unchanged when we use book leverage as dependent variable. Specifically, the coefficient estimates (tstatistics) of Accr, Smth, Corr and P_EM are 0.2522(5.7574), 0.6867(4.0992), $0.6105(3.1691)$ and 0.2494(4.0229), respectively.

[Insert Table 5

Our results are consistent with $\mathbf{H 1}$. That is, when earnings management is used as a proxy for information asymmetry between corporate insiders and outside investors, these results indicate that higher earnings management activities increase the demand for debt as an external control mechanism in reducing agency costs of free cash flow. Moreover, our results are as well consistent with the pecking order theory that the adverse selection costs associated wit information asymmetry are higher for external equity than debt.

Table 5 also shows that the coefficient estimates of Tang in all regressions are positively significantly at $1 \%$ level. It indicates that the firms with more tangible assets have lower expected distress costs. Thus, tend to have higher leverage ratios. Prof is negatively significantly at $1 \%$ level. It is consistent with pecking order theories which argues that more profitable firms rely on

\footnotetext{
${ }^{13}$ We scale Accr, Smth, Corr and $P_{-} E M$ by 100 in all multivariate regressions. Thus, the coefficient estimates of earnings management measures and their interactions with institutional environment variables should interpreted as \%. For example, column 4 of Table 5 shows that the coefficient estimate of $P_{-} E M$ is 0.1584 . It indicates that 1 unit increase in $P_{-} E M$ increases market leverage by $0.1584 \%$.
} 
internal finance over external funds. Size is positively significantly at $1 \%$ level. It indicates that larger firms that have lower default risk with better reputation tend to have higher leverage. $M T B$ is negatively significantly at $1 \%$ level for book leverage regressions (columns 5 to 8 ). It shows that growth firms face higher financial distress cost. IndMed is positively significantly at $1 \%$ level. It indicates that managers tend to use industry median leverage as a benchmark as they build their own capital structures. In sum, the results of the firm and industry characteristics are consistent with Titman and Wessels (1988), Lemmon, Roberts, and Zender (2008), and Frank and Goyal (2009).

Next, we examine the empirical model (equation (1)) in Section 3 . Our model includes an earnings management variable and its interaction with each macro-level institutional environment variable to access the following research question: whether the earnings management - corporate leverage relation is influenced by macro-level institutional environments.

Our first institutional environment variable is $\mathrm{Leg}_{-} \mathrm{Com}$. Leg_Com is a dummy variable that measures a country's legal origin. It equals 1 if the country's legal system is based on common law, and 0 for civil law countries. In Table 6, we include 8 different specifications. Panel A (B) of Table 6 reports estimation results for market (book) leverage. In columns 1, 3, 5 and 7, we have one of our four earnings management variables (Accr, Smth, Corr and $\left.P_{-} E M\right)$ and its interaction with $\mathrm{Leg}_{-} \mathrm{Com}$ in the corresponding regression. In columns 2, 4, 6 and 8, we include the interactions of $\mathrm{Leg}_{-} \mathrm{Com}$ and firm and industry characteristics in all regressions. By doing so, we control for the role of legal origin on the relations between firms' leverages and their firm and industry characteristics in estimating how legal origin affects the earnings management - corporate leverage relation. Control variables are included in the estimations but not reported in the tables for brevity. This structure is applied to all subsequent results tables.

[Insert Table 6]

Our regression results in columns 1, 3, 5 and 7 of Panel A show that the coefficient estimates of our earnings management variables are positively 
significant at $1 \%$ level. Specifically, the coefficient estimates (t-statistics) of Accr, Smth, Corr, and P_EM are 0.3455(9.4210), 1.1904(5.2806), 1.1495(2.7682), and 0.4739 (4.0878), respectively. Columns 2, 4, 6 and 8 show that results are consistent when we add the interactions of $\mathrm{Leg}_{-} \mathrm{Com}$ and firm and industry characteristics. In addition, the book leverage results reported in Panel $\mathrm{B}$ are consistent to our finding in Panel A. In sum, for different earnings management and leverage variables used above, we document significant results that are consistent with $\mathbf{H 1}$ that firms with higher level of earnings management tend to have higher financial leverage ratios. 14

Next, we turn to examine how institutional environments reshape the earnings management - corporate leverage sensitivity across countries. In particular, our focus here is the interaction of earnings management and Leg_Com. Panel A shows that, for market leverage, the coefficient estimates of $P \_E M \times L e g C o m$ in all specifications (except column 6) are negatively significant. Specifically, the coefficient estimates (t-statistics) of $P_{-} E M \times$ LegCom in columns 1, 3, 5 and 7 are $-0.1502(-2.0711),-1.0410(-3.5639)$, $-0.8664(-1.8371)$, and $-0.4055(-2.8985)$, respectively. The results are economically significant across different earnings management measures. For example, column 7 shows that the coefficient estimate of $P_{-} E M \times L e g C o m$ is -0.4055 . It indicates that, for the countries based on common law $\left(\operatorname{Leg}_{-} \mathrm{Com}=1\right)$, legal origin reduces the effect of $P_{-} E M$ on market leverage by $0.4055 \%$ compared to civil law countries, ceteris paribus. Thus, one standard deviation increase in $P_{-} E M$ leads to about $0.08 \%(=1.22 \times(0.4739 \%-$ $0.4055 \% \times 1)$ ) increase in market leverage.

The results are qualitatively unchanged in the regressions including the interactions of $\mathrm{Leg}_{-} \mathrm{Com}$ and firm and industry characteristics. Specifically, the coefficient estimates (t-statistics) of interactions in columns 2, 4, 6 and 8 are $-0.1562(-2.1747),-0.9664(-3.2727),-0.5784(-1.1770)$, and $-0.3393(-2.3089)$, respectively. Panel B reports the coefficient estimates

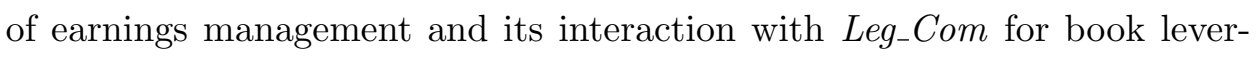
age. The book leverage results appear to confirm our finding in Panel A for

\footnotetext{
${ }^{14}$ The coefficient estimates of earnings management variables remain positively significant if we use other $I E$ variables. (e.g., P_Enfor, P_SH, P_Acct, P_K09, and P_K04)
} 
market leverage.

The results are consistent with $\mathbf{H 2}$ that financial leverage tends to be less positively correlated with earnings management in countries based on common law than civil law. La Porta, Lopez-de-Silanes, Shleifer, and Vishny (1998) suggest that the countries with legal systems based on common law provide better investor protection countries than in civil law countries. Thus, it is more difficulty for managers to expropriate investments from investors in common law countries. Therefore, common law legal system provides a better controlling mechanism than civil law, and reduces the demand for "costly" debt in mitigating agency conflicts.

In addition, Table 7 examine $\mathbf{H 2}$ by using $P_{-}$Enfor as an institutional environment variable. The coefficient estimates of the interactions between earnings management (Smth, Corr and $\left.P_{-} E M\right)$ and $P_{-}$Enfor are negatively significant for both market (except column 4 of Panel A) and book leverage regressions. Specifically, for market leverage regressions, the coefficient estimates (t-statistics) of interactions in columns 3, 5, and 7 of Panel A are $-0.4100(-1.7201),-0.7005(-2.5279)$, and $-0.2114(-2.2146)$, respectively. Similar to Leg_Com, P_Enfor also plays an economically significant role in shaping earnings management - corporate leverage sensitivity. For example, column 7 shows that the coefficient estimates of $P_{-} E M$ and $P \_E M \times P \_E n f o r$ are 0.6225 and -0.2144 , respectively. Given the mean of $P_{-}$Enfor in Table $2,0.80$. The results indicate that, on average, one standard deviation increase in $P \_E M$ leads to about $0.55 \%$ (= $1.22 \times(0.6225 \%-0.2144 \% \times 0.8))$ increase in market leverage. The results are qualitatively unchanged by controlling the interactions of Leg_Enfor and firm and industry characteristics which are reported in columns 4, 6, and 8 . The Accr $\times P \_$Enfor are not significant in columns 1 and 2 . The results are qualitatively unchanged for book leverage regressions which are reported in Panel B.

$$
\text { [Insert Table } 7
$$

The results confirm the role of enforcement in shaping the impact of earnings management on capital structure decisions. It shows that financial 
leverage tends to be less positively correlated with earnings management in countries with stronger legal enforcement. These results are in accordance with the notions that strong legal enforcement enforce investors' rights in the time of need, and mitigate the agency conflicts with no incremental costs. Thus, the earnings management - corporate leverage relation is less pronounced in the countries with strong legal enforcement.

In sum, we document two novel findings that support our hypotheses (H1 and H2) in Section 2. Precisely, we find that leverage ratios increase in earnings management activities and this positive relation is attenuated in counties with strong institutional environments, in particular, common law legal system and strong enforcement.

\section{Robustness tests}

\subsection{Alternative measures of institutional environments}

In this section, we test our hypotheses with alternative institutional environment variables. As a first robustness check of our results, we examine macrolevel institutional environment measures from the aspects of shareholder protection $\left(P_{-} S H\right)$ and accounting information quality $\left(P_{-} A c c t\right)$. Panel A of Table 8 shows the coefficient estimates of the interaction terms between earnings management (Accr, Smth and $\left.P_{-} E M\right)$ and $P_{-} S H$ are negatively significant for market leverage regressions. In addition, Panel A of Table 9 reports the negatively significant coefficient estimates for the interaction terms between earnings management (Smth, Corr and P_EM) and P_Acct for market leverage regressions.

Panel B of Table $8(9)$ reports the coefficient estimates of earnings management and its interaction with $P_{-} S H$ ( $\left.P_{-} A c c t\right)$ for book leverage. The results are qualitatively unchanged and confirm our finding in Panel A for market leverage. In sum, we obtain qualitatively consistent results across difference earnings management and leverage measures by using $P_{-} S H$ or $P_{-}$Acct as institutional setting measure. They suggest that strong institutional environments, in particular, better shareholder protection and ac- 
counting information quality, could protect investors and reduce the earnings management - corporate leverage sensitivity.

\section{[Insert Table 8}

[Insert Table 9

Furthermore, we examine other alternative measures of institutional environments (governance index $\left(P_{-} K 09\right)$ and ethics index $\left(P_{-} K 04\right)$ ), and the results are presented in Tables 10 and 11 . The results with these variables are largely similar to prior results and hence consistent with our hypotheses. In particular, the earnings management variables are positively significant, and their interactions with $P_{-} K 09$ or $P_{-} K 04$ are negatively significant (except Accr) for both market and book leverage regressions. The results confirm our findings that presented in the previous section. They suggest that corporate leverage is less sensitive to earnings management in the countries with high governance indicator and ethic index.

[Insert Table 10

[Insert Table 11$]$

In addition, we estimate our model with each sub-index of $P_{-}$Enfor, $P_{-} S H, P_{-}$Acct, $P_{-} K 09$, and $P_{-}$K04. The results are qualitatively consistent with our hypotheses and not reported for brevity. 15

\subsection{Excluding the U.S. in the sample}

Since US firms account for a substantial fraction of our population of firms, our results are possibly driven by US observations, not by institutional environments. ${ }^{16}$ To address this issue, we construct a Non-US sub-sample by removing all US firms from the full sample and examine the model across difference earnings management, leverage and institutional setting measures.

\footnotetext{
${ }^{15}$ The results are available upon request.

${ }^{16}$ Specifically, US has 44, 832 firm-year observations and accounts for $27 \%$ of the full sample.
} 
The results are consistent with the full sample results and not reported to save space 17

\subsection{First-difference regression}

We examine the relation between corporate leverage and earnings management by using the first-difference regression model to address the endogeneity problem. We reestimate the baseline regression models reported in Table 5 by regressing the change in leverage on the 1 year lag of the changes in earnings management, and firm, industry and country control variables. Table 12 reports the coefficient estimates of earnings management variables are positively significant at $1 \%$ level (except Accr). For example, column 4 shows that $P_{-} E M$ is positively associated with market leverage with coefficient estimate (t-statistic) $0.1939(4.2008)$. It indicates that 1 unit increase in $\triangle P_{-} E M$ increases $\Delta M L$ by $0.1939 \%$ unit. In sum, the results confirm H1 which higher earnings management is associated with higher corporate leverage.

[Insert Table 12$]$

\section{Conclusion}

In this paper, we shed new light on firms' capital structure choices employing a comprehensive sample of 25,798 firms across 37 countries over two decades. We focus on the relation between earnings and financial leverage and the role of institutional environments in shaping this relation. Two novel results emerge from this study.

First, we find robust evidence that firms engaging in higher earnings management activities on average have higher leverage. Combined with the notion that a firm's earnings management reflects the information asymmetry between managers and investors, this result is consistent with the agency theory of free cash flow, that is, higher earnings management activities increase the demand for debt as an external control mechanism.

\footnotetext{
${ }^{17}$ Non-US results are available upon request.
} 
Second, we document that the positive relation between earnings management and capital structure is much less pronounced in countries with better institutional environments. This finding supports the notions that investors in the countries with strong institutional environments are more reliant on "cheap" macro-level institutional settings than using debt in mitigating agency conflicts.

We conduct several robustness checks. Our results are robust to different earnings management measures, different leverage ratios, different institutional environment variables, and different samples.

There are policy implications. For firms operated in countries with strong (weak) institutional environments, managers' earnings management activities are less (more) tolerant by investors. The side effect of earnings management on leverage seems to be at least partially offset by institutional environments. So, institutional environments should be improved to maintain higher accounting credibility in firms. 


\section{References}

Antoniou, Antonios, Yilmaz Guney, and Krishna Paudyal, 2008, The determinants of capital structure: Capital market-oriented versus bankoriented institutions, Journal of Financial and Quantitative Analysis 43, 59-92.

Booth, Laurence, Varouj Aivazian, Asli Demirguc-Kunt, and Vojislav Maksimovic, 2001, Capital structures in developing countries, The Journal of Finance 56, 87-130.

Bushman, Robert M., Joseph D. Piotroski, and Abbie J. Smith, 2004, What determines corporate transparency?, Journal of Accounting Research 42, $207-252$.

Dechow, Patricia M., Richard G. Sloan, and Amy P. Sweeney, 1996, Causes and consequences of earnings manipulation: An analysis of firms subject to enforcement actions by the sec*, Contemporary Accounting Research $13,1-36$.

Demirguc-Kunt, Asli, and Vojislav Maksimovic, 1998, Law, finance, and firm growth, Journal of Finance 53, 2107-2137.

—, 1999 , Institutions, financial markets, and firm debt maturity, Journal of Financial Economics 54, 295-336.

Djankov, Simeon, Rafael La Porta, Florencio Lopez-de-Silanes, and Andrei Shleifer, 2008, The law and economics of self-dealing, Journal of Financial Economics 88, 430-465.

Fan, Joseph P. H., Sheridan Titman, and Garry Twite, 2012, An international comparison of capital structure and debt maturity choices, Journal of Financial and Quantitative Analysis 47, 23-56.

Frank, Murray Z., and Vidhan K. Goyal, 2009, Capital structure decisions: Which factors are reliably important?, Financical Management 38, 1-37. 
Giannetti, Mariassunta, 2003, Do better institutions mitigate agency problems? evidence from corporate finance choices, Journal of Financial and Quantitative Analysis 38, 185-212.

Halling, Michael, Jin Yu, and Josef Zechner, 2012, Leverage dynamics of the business cycle, Working Paper.

Healy, Paul M, and James M Wahlen, 1999, A review of the earnings management literature and its implications for standard setting, Accounting Horizons 13, 365-383.

Jensen, Michael C., 1986, Agency costs of free cash flow, corporate finance, and takeovers, American Economic Review 76, 323-329.

Jensen, Michael C, 1993, The modern industrial revolution, exit, and the failure of internal control systems, Journal of Finance 48, 831-80.

Jensen, Michael C., and William H. Meckling, 1976, Theory of the firm: Managerial behavior, agency costs and ownership structure, Journal of Financial Economics 3, 305-360.

Kaufmann, Daniel, 2004, Corruption, governance and security: Challenges for the rich countries and the world, Policy research working paper series, World Bank, Washington, DC.

- Aart Kraay, and Massimo Mastruzzi, 2009, Governance matters viii : aggregate and individual governance indicators 1996-2008, Policy research working paper series, World Bank, Washington, DC.

La Porta, Rafael, Florencio Lopez-De-Silanes, Andrei Shleifer, and Robert Vishny, 2002, Investor protection and corporate valuation, The Journal of Finance 57, 1147-1170.

La Porta, Rafael, Florencio Lopez-de-Silanes, Andrei Shleifer, and Robert W. Vishny, 1998, Law and finance, Journal of Political Economy 106, 1113-1155. 
Lemmon, Michael L., Michael R. Roberts, and Jaime F. Zender, 2008, Back to the beginning: Persistence and the cross-section of corporate capital structure, The Journal of Finance 63, 1575-1608.

Leuz, Christian, Dhananjay Nanda, and Peter D. Wysocki, 2003, Earnings management and investor protection: an international comparison, Journal of Financial Economics 69, 505-527.

Mclean, R. David, Tianyu Zhang, and Mengxin Zhao, 2012, Why does the law matter? investor protection and its effects on investment, finance, and growth, The Journal of Finance 67, 313-350.

Myers, Stewart C, 1984, The capital structure puzzle, Journal of Finance $39,575-92$.

Myers, Stewart C., and Nicholas S. Majluf, 1984, Corporate financing and investment decisions when firms have informationthat investors do not have, Journal of Financial Economics 13, 187-221.

Oztekin, Ozde, and Mark J. Flannery, 2012, Institutional determinants of capital structure adjustment speeds, Journal of Financial Economics 103, $88-112$.

Rajan, Raghuram G., and Luigi Zingales, 1995, What do we know about capital structure? some evidence from international data, Journal of Finance 50, 1421-60.

Titman, Sheridan, and Roberto Wessels, 1988, The determinants of capital structure choice, Journal of Finance 43, 1-19. 
Table 1: The sample: This table provides a description of the sample. Number of years, firms, and firm-years of each country are reported in the table.

\begin{tabular}{|c|c|c|c|}
\hline Market & Number of years & Number of firms & Number of firm-years \\
\hline Australia & 21 & 1021 & 4340 \\
\hline Austria & 21 & 89 & 635 \\
\hline Belgium & 21 & 124 & 977 \\
\hline Canada & 21 & 1106 & 5513 \\
\hline China & 16 & 1321 & 5616 \\
\hline Chile & 19 & 106 & 746 \\
\hline Denmark & 21 & 152 & 1391 \\
\hline Ireland & 14 & 64 & 462 \\
\hline Finland & 21 & 142 & 1312 \\
\hline France & 21 & 862 & 6177 \\
\hline Germany & 21 & 810 & 5828 \\
\hline Greece & 21 & 264 & 1650 \\
\hline Hong Kong & 21 & 781 & 3879 \\
\hline Indonesia & 16 & 228 & 1447 \\
\hline India & 13 & 332 & 1240 \\
\hline Israel & 13 & 88 & 407 \\
\hline Italy & 21 & 269 & 1880 \\
\hline Japan & 21 & 3655 & 31145 \\
\hline South Korea & 20 & 943 & 4831 \\
\hline Malaysia & 21 & 728 & 3949 \\
\hline Netherlands & 21 & 182 & 1748 \\
\hline Norway & 21 & 199 & 1296 \\
\hline New Zealand & 21 & 92 & 525 \\
\hline Pakistan & 15 & 71 & 483 \\
\hline Poland & 13 & 178 & 589 \\
\hline Portugal & 21 & 74 & 548 \\
\hline Philippines & 17 & 110 & 686 \\
\hline South Africa & 21 & 300 & 1908 \\
\hline Singapore & 21 & 558 & 2761 \\
\hline Spain & 21 & 140 & 1119 \\
\hline Sweden & 21 & 323 & 2092 \\
\hline Switzerland & 21 & 202 & 1905 \\
\hline Thailand & 18 & 400 & 2470 \\
\hline Turkey & 17 & 172 & 996 \\
\hline Taiwan & 17 & 1191 & 5150 \\
\hline United Kingdom & 21 & 1976 & 13792 \\
\hline United States & 21 & 6545 & 44832 \\
\hline Total & & 25,798 & 166,325 \\
\hline
\end{tabular}


Table 2: Descriptive statistics: This table presents the descriptive statistics of firm and industry level variables (Panel A), country control variables (Panel B), and institutional environment variables (Panel C). The sample period is from 1989 to 2009. Summary statistics in Panel A are based on a panel of firm-year observations, in Panel B based on a panel of country-year observations, and in Panel $\mathrm{C}$ based on a cross section of countries. All variables are defined in Appendix A

Panel A: Firm and industry variables

\begin{tabular}{|c|c|c|c|c|c|c|}
\hline & $\mathrm{N}$ & Mean & Median & Std. Dev. & Minimum & Maximum \\
\hline \multicolumn{7}{|c|}{ Leverage ratios : } \\
\hline$M L$ & 166325 & 0.27 & 0.22 & 0.25 & 0.00 & 1.00 \\
\hline$B L$ & 166325 & 0.23 & 0.21 & 0.19 & 0.00 & 1.00 \\
\hline \multicolumn{7}{|c|}{ Earnings management measures : } \\
\hline Accr & 166163 & 1.20 & 0.70 & 1.84 & 0.10 & 22.93 \\
\hline Smth & 166163 & -0.66 & -0.59 & 0.42 & -2.97 & -0.04 \\
\hline Corr & 145470 & 0.77 & 0.93 & 0.34 & -0.89 & 1.00 \\
\hline$P_{-} E M$ & 145470 & 0.03 & 0.37 & 1.22 & -6.75 & 1.55 \\
\hline \multicolumn{7}{|c|}{ Firm and industry control variables : } \\
\hline Tang & 166325 & 0.32 & 0.29 & 0.22 & 0.00 & 0.94 \\
\hline Prof & 166325 & 0.09 & 0.10 & 0.14 & -0.69 & 0.47 \\
\hline Size & 166325 & 12.52 & 12.43 & 1.90 & 4.87 & 17.92 \\
\hline$M T B$ & 166325 & 1.30 & 0.93 & 1.48 & 0.09 & 26.88 \\
\hline IndMed $(M)$ & 166325 & 0.23 & 0.21 & 0.16 & 0.00 & 0.98 \\
\hline IndMed (B) & 166325 & 0.20 & 0.20 & 0.10 & 0.00 & 0.86 \\
\hline
\end{tabular}

Panel B: Country control variables

\begin{tabular}{lcccccc}
\hline & $\mathrm{N}$ & Mean & Median & Std. Dev. & Minimum & Maximum \\
\hline$G D P C$ & 712 & 4.10 & 4.31 & 0.53 & 2.57 & 4.98 \\
$M C A P$ & 712 & 79.74 & 59.30 & 71.48 & 4.47 & 617.05 \\
$G G D P$ & 712 & 3.65 & 3.53 & 3.08 & -13.13 & 14.20 \\
\hline
\end{tabular}

Panel C: Institutional environment variables

\begin{tabular}{lcccccc}
\hline & N & Mean & Median & Std. Dev. & Minimum & Maximum \\
\hline LegCom & 35 & 0.40 & 0.00 & 0.50 & 0.00 & 1.00 \\
P_Enfor & 35 & 0.80 & 1.53 & 1.88 & -3.61 & 2.80 \\
P_SH & 35 & 0.35 & 0.24 & 1.24 & -1.64 & 2.44 \\
P_Acct & 32 & 0.16 & 0.48 & 1.14 & -2.34 & 1.76 \\
P_K09 & 37 & 1.87 & 2.30 & 1.42 & -1.35 & 3.46 \\
$P_{-}$K04 & 37 & 1.57 & 1.95 & 2.28 & -3.05 & 4.70 \\
\hline \hline
\end{tabular}


Table 3: Earnings management measures: This table provides a description of the country median of earnings management measures (Accr, Smth, Corr and P_EM). All variables are defined in Appendix $\mathrm{A}$.

\begin{tabular}{lcccc}
\hline Market & Accr & Smth & Corr & $P_{-} E M$ \\
\hline Australia & 0.60 & -0.69 & 0.90 & 0.14 \\
Austria & 0.83 & -0.36 & 0.98 & 0.90 \\
Belgium & 0.73 & -0.50 & 0.96 & 0.62 \\
Canada & 0.64 & -0.66 & 0.90 & 0.19 \\
China & 0.90 & -0.35 & 0.98 & 0.90 \\
Chile & 0.52 & -0.49 & 0.96 & 0.63 \\
Denmark & 0.63 & -0.45 & 0.96 & 0.72 \\
Ireland & 0.50 & -0.54 & 0.94 & 0.53 \\
Finland & 0.64 & -0.55 & 0.94 & 0.52 \\
France & 0.71 & -0.52 & 0.95 & 0.55 \\
Germany & 0.88 & -0.48 & 0.95 & 0.63 \\
Greece & 0.91 & -0.35 & 0.98 & 0.93 \\
Hong Kong & 0.80 & -0.60 & 0.92 & 0.34 \\
Indonesia & 0.76 & -0.57 & 0.94 & 0.42 \\
India & 0.65 & -0.48 & 0.96 & 0.59 \\
Israel & 0.74 & -0.57 & 0.93 & 0.42 \\
Italy & 0.77 & -0.46 & 0.96 & 0.70 \\
Japan & 0.70 & -0.53 & 0.94 & 0.52 \\
South Korea & 0.84 & -0.54 & 0.94 & 0.50 \\
Malaysia & 0.89 & -0.49 & 0.95 & 0.58 \\
Netherlands & 0.58 & -0.47 & 0.96 & 0.68 \\
Norway & 0.83 & -0.63 & 0.89 & 0.24 \\
New Zealand & 0.54 & -0.51 & 0.96 & 0.58 \\
Pakistan & 0.59 & -0.49 & 0.95 & 0.64 \\
Poland & 0.84 & -0.51 & 0.95 & 0.52 \\
Portugal & 0.95 & -0.40 & 0.98 & 0.84 \\
Philippines & 0.85 & -0.50 & 0.95 & 0.55 \\
South Africa & 0.46 & -0.62 & 0.92 & 0.34 \\
Singapore & 0.82 & -0.52 & 0.95 & 0.55 \\
Spain & 0.66 & -0.49 & 0.96 & 0.61 \\
Sweden & 0.67 & -0.68 & 0.90 & 0.17 \\
Switzerland & 0.59 & -0.47 & 0.96 & 0.66 \\
Thailand & 0.74 & -0.56 & 0.94 & 0.41 \\
Turkey & 0.72 & -0.59 & 0.92 & 0.36 \\
Taiwan & 0.78 & -0.53 & 0.94 & 0.52 \\
United Kingdom & 0.58 & -0.64 & 0.91 & 0.27 \\
United States & 0.64 & -0.74 & 0.86 & -0.04 \\
\hline Mean & 0.72 & -0.53 & 0.94 & 0.52 \\
Median & 0.72 & -0.52 & 0.95 & 0.54 \\
Std.Dev. & 0.13 & 0.09 & 0.03 & 0.22 \\
Min & 0.46 & -0.74 & 0.86 & -0.04 \\
Max & 0.95 & -0.35 & 0.98 & 0.93 \\
\hline \hline & & &
\end{tabular}




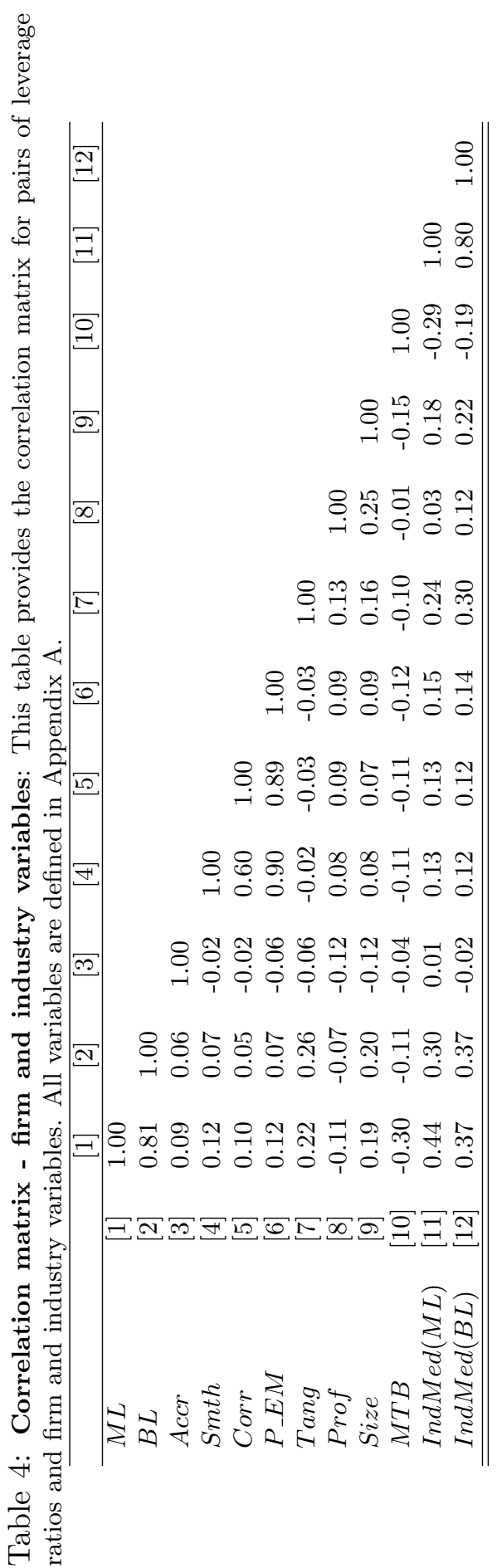




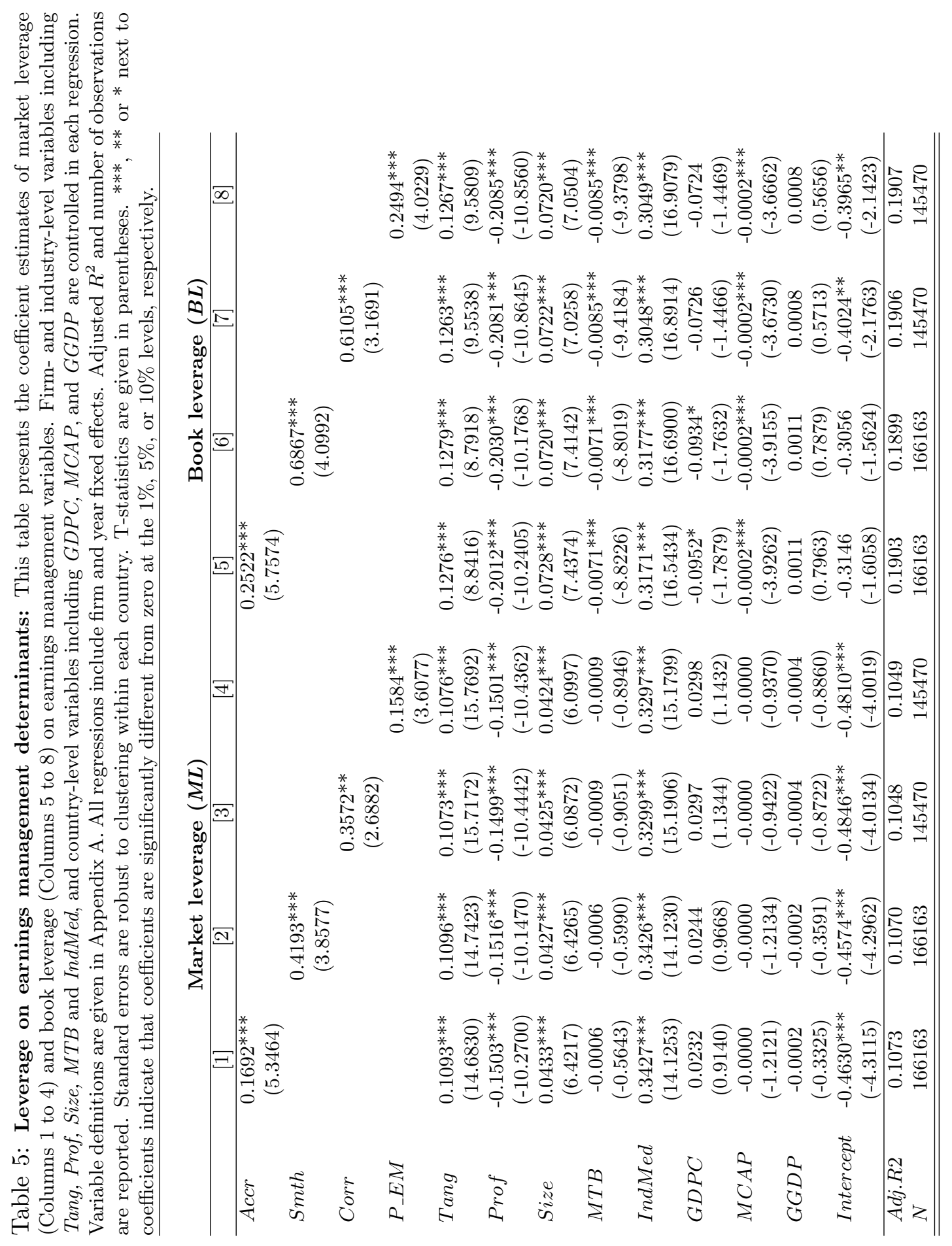




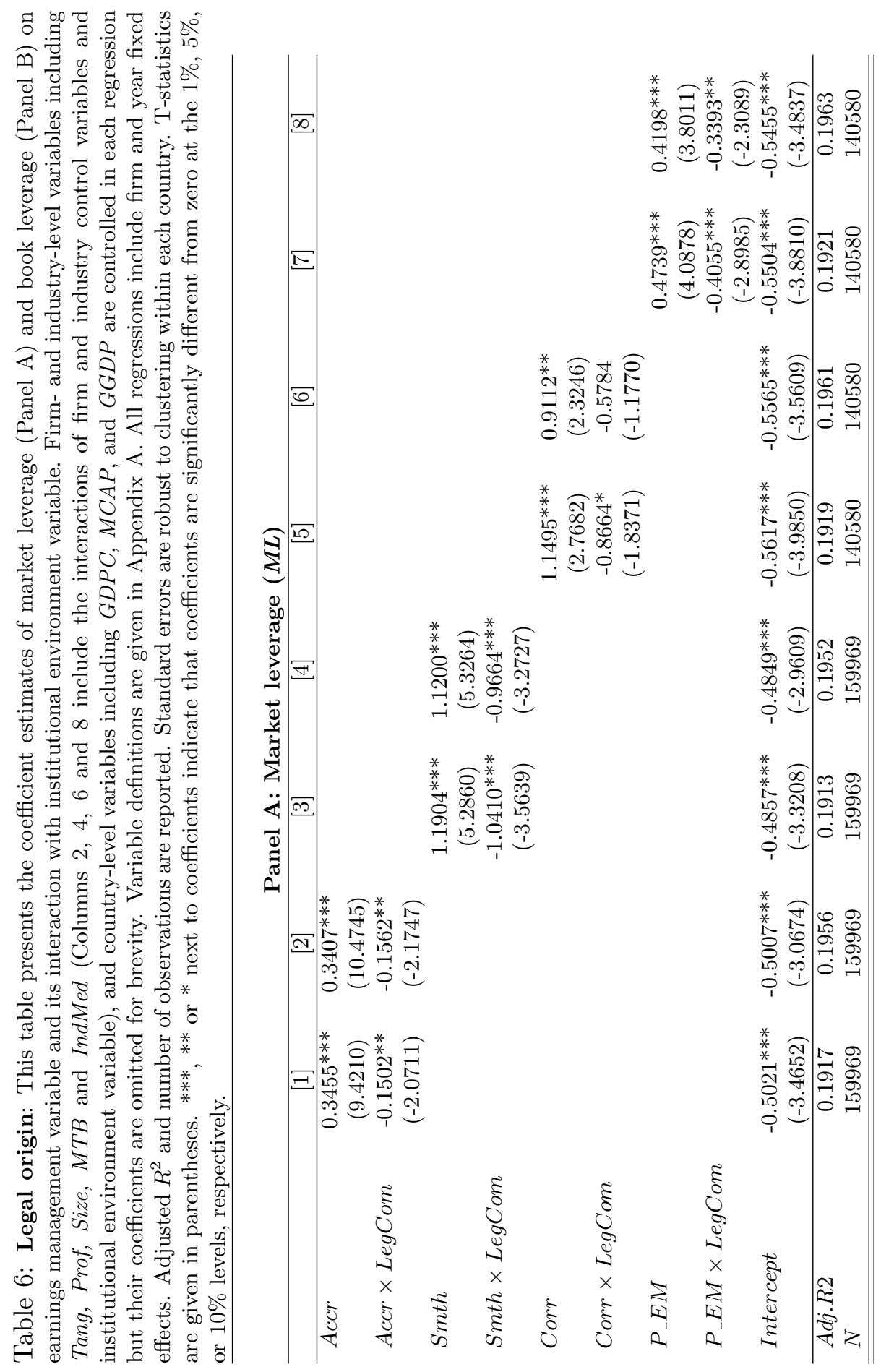




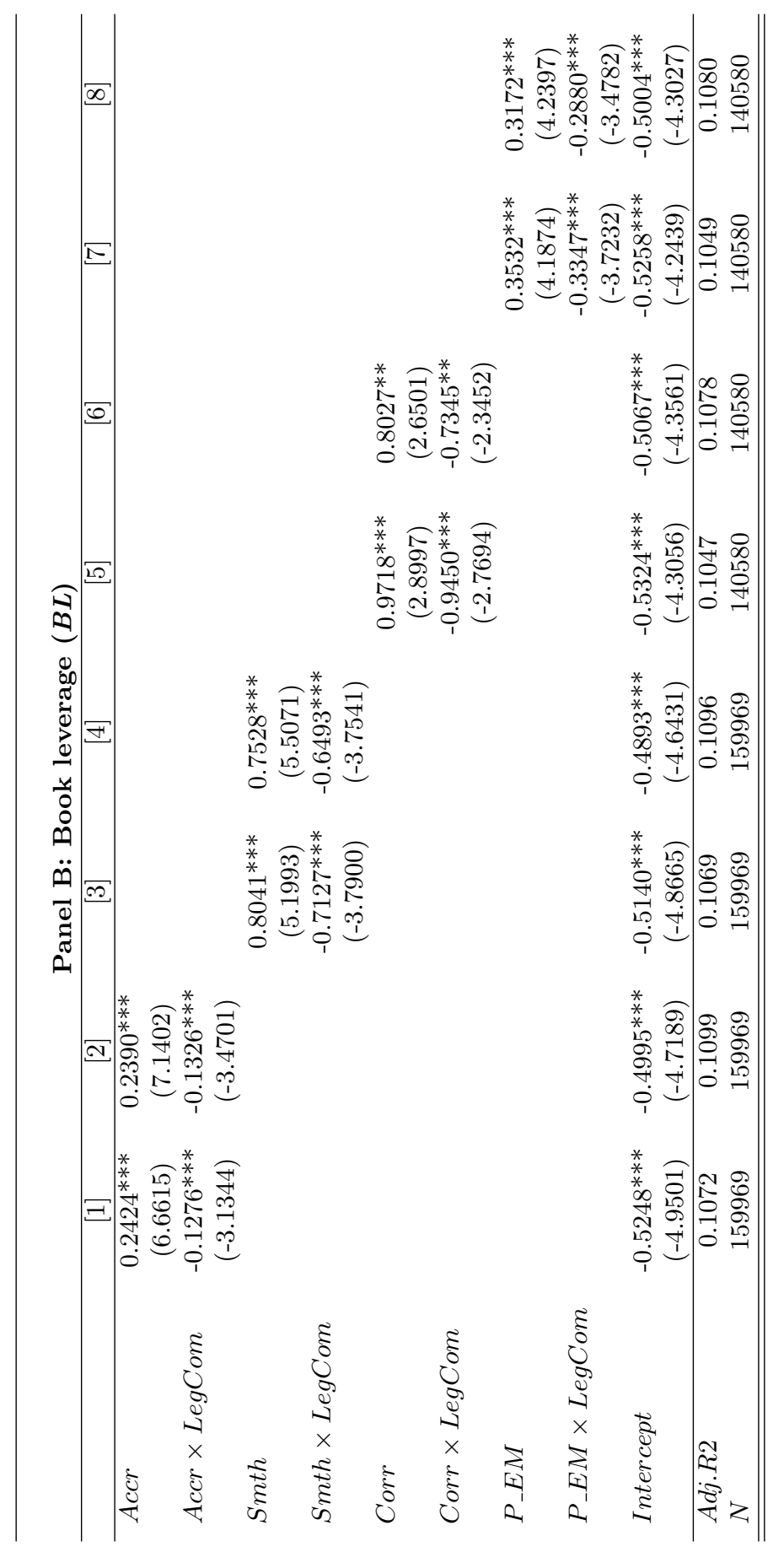




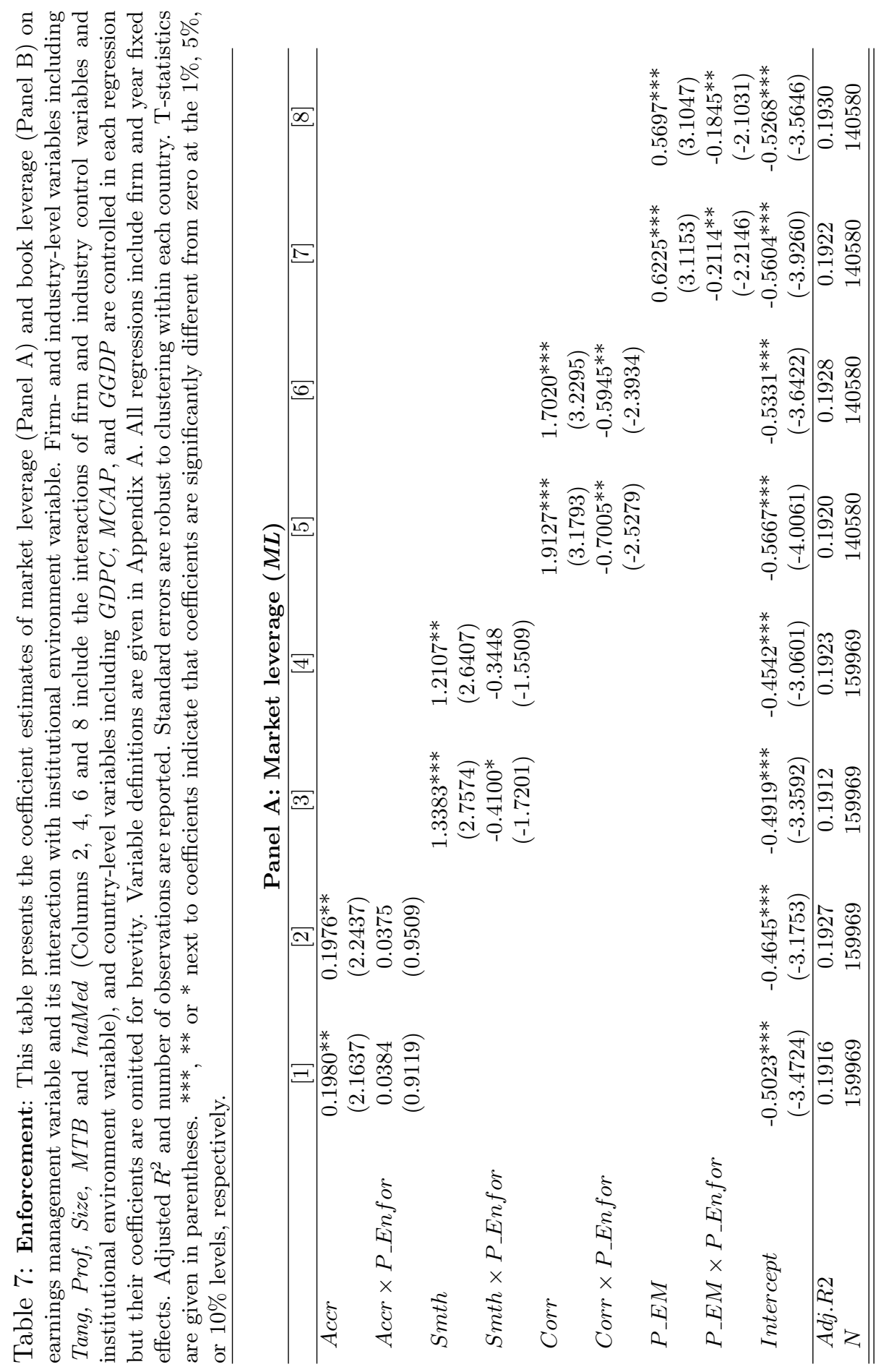




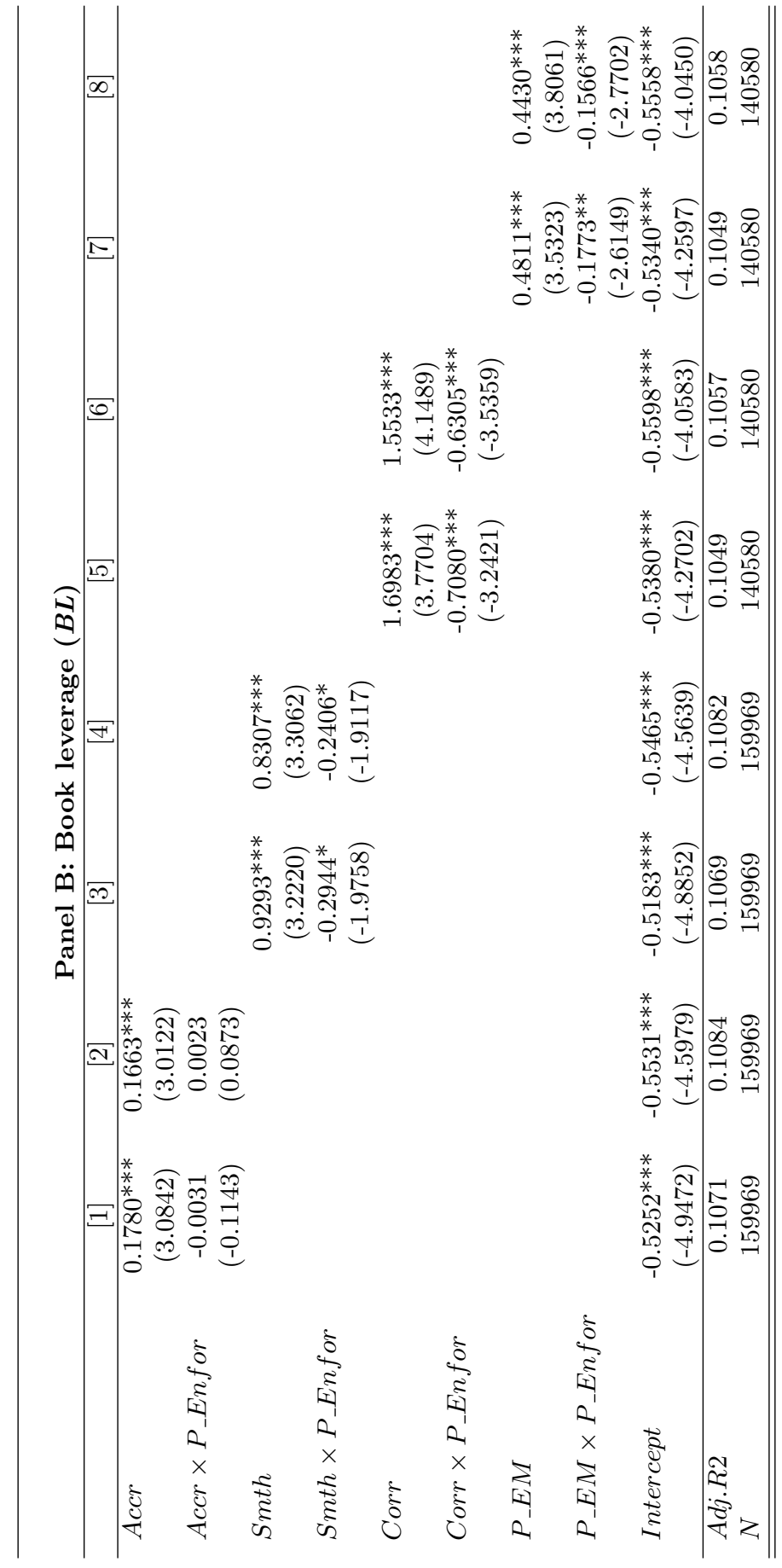




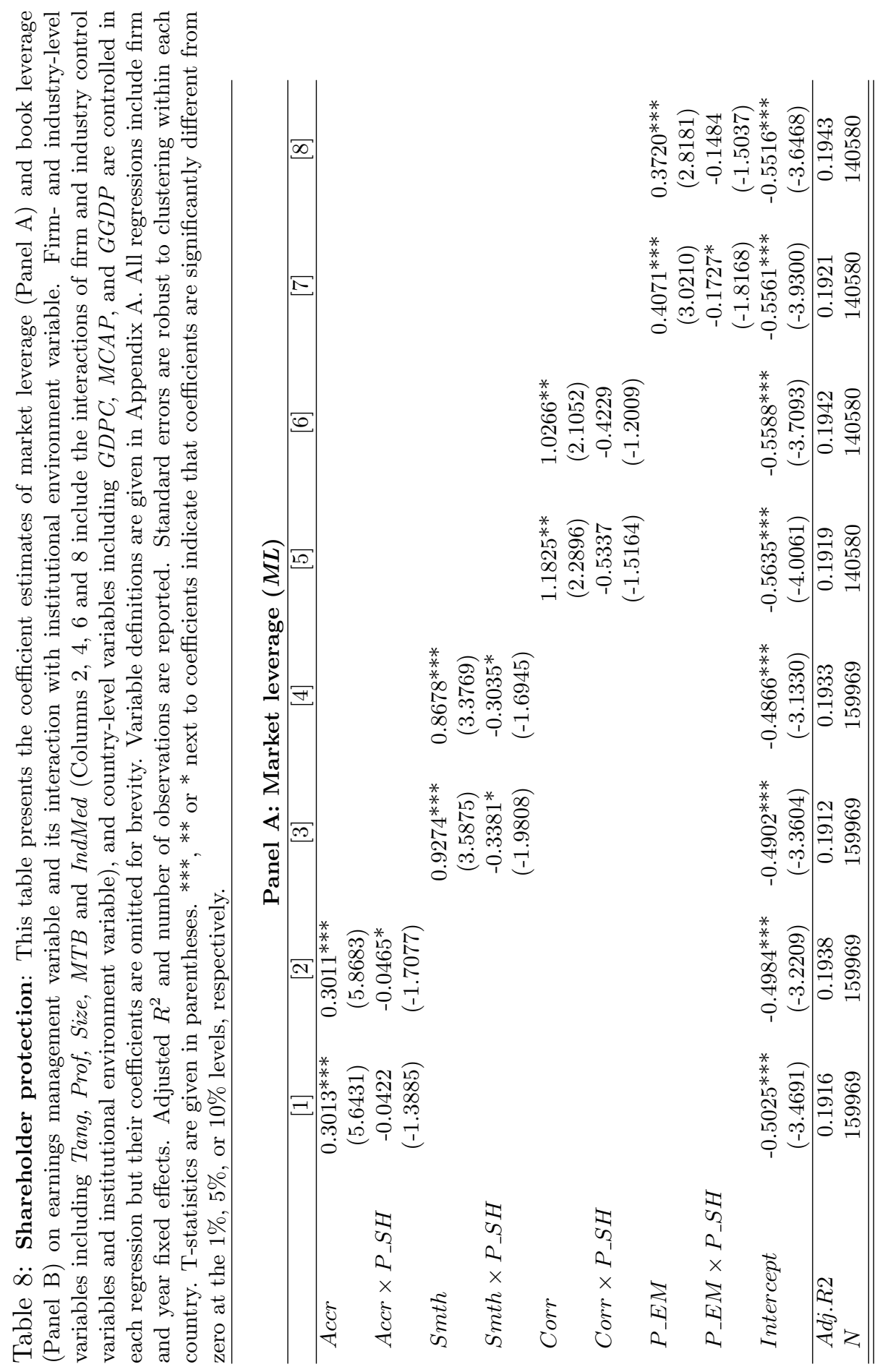




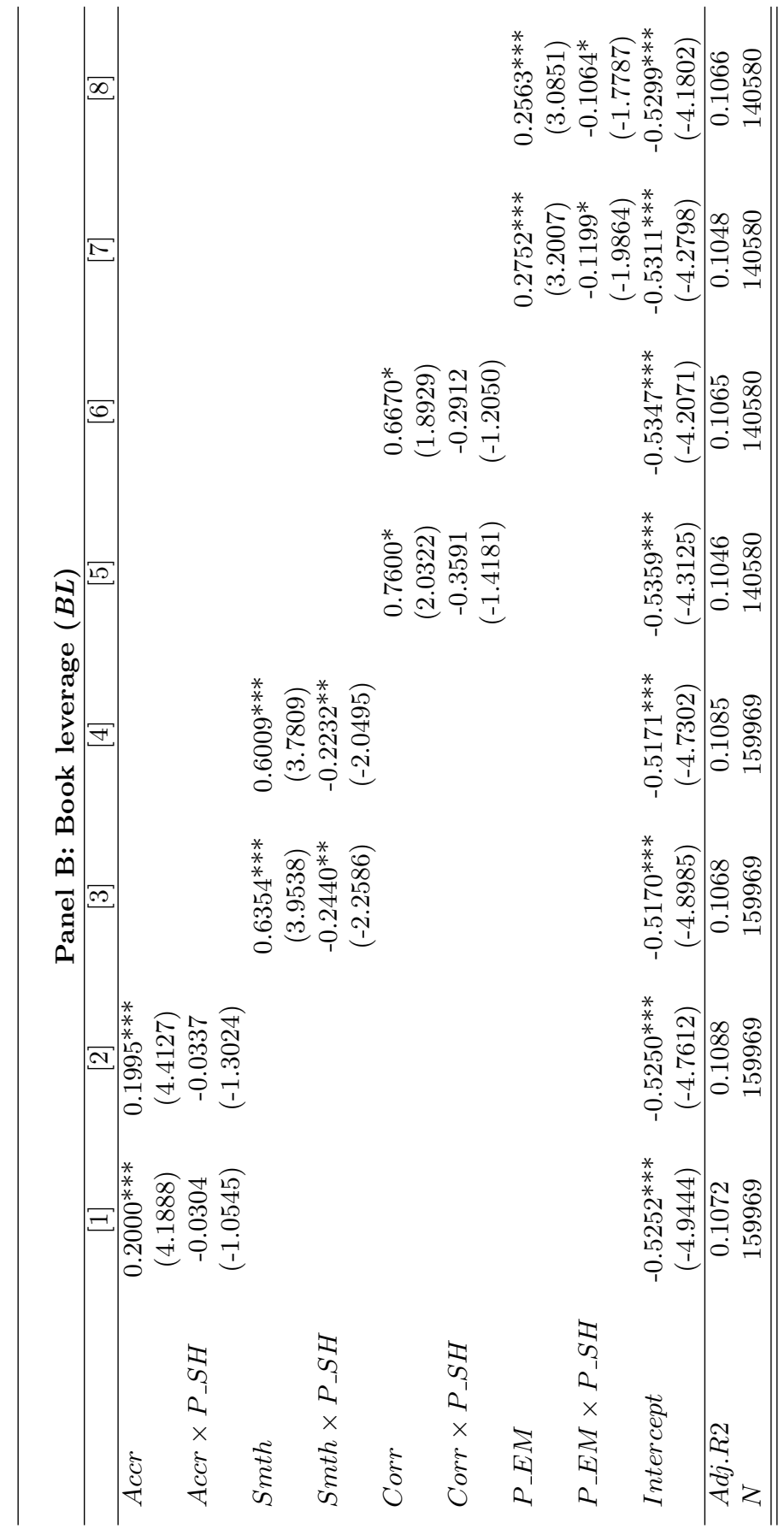




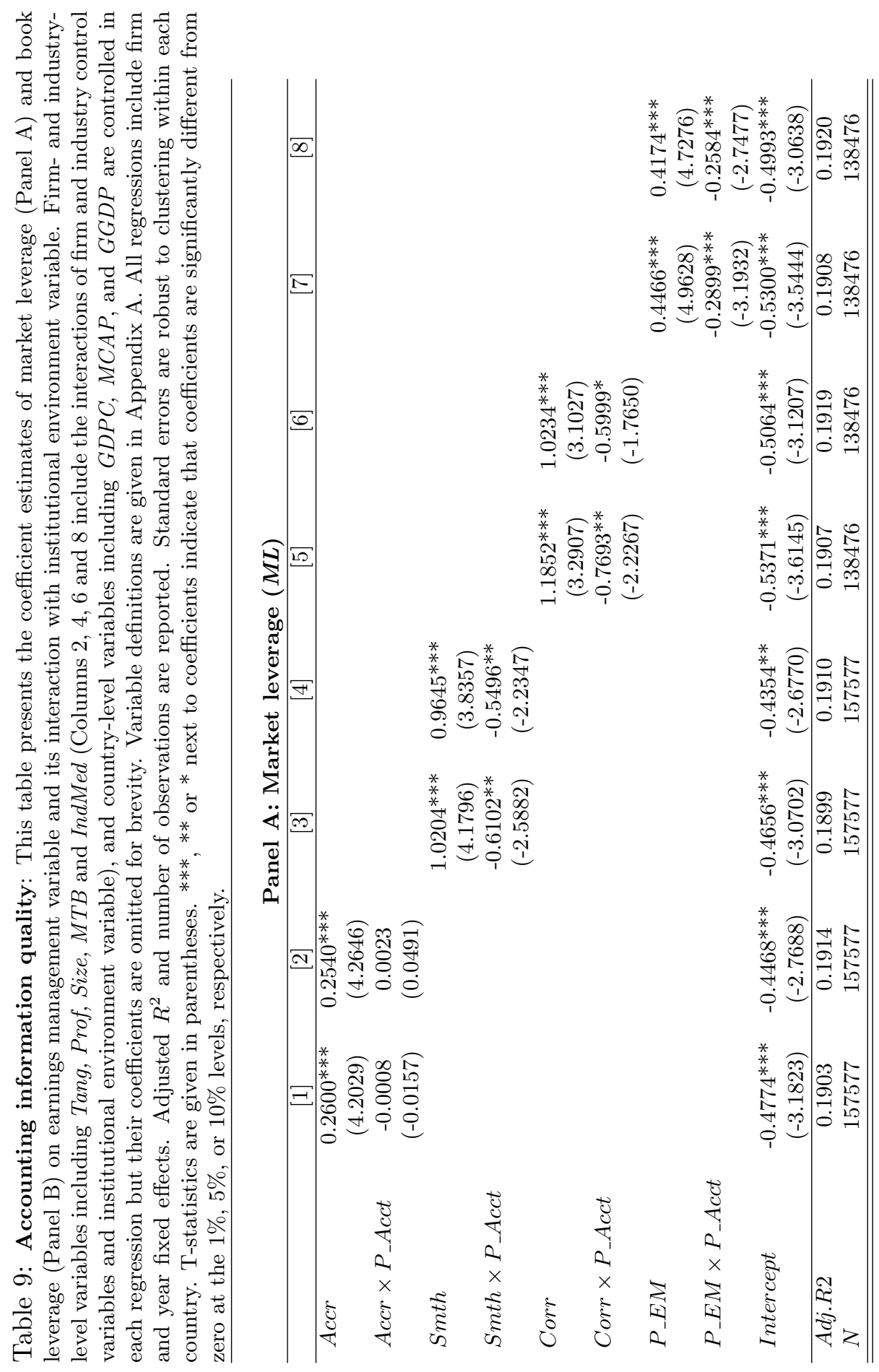




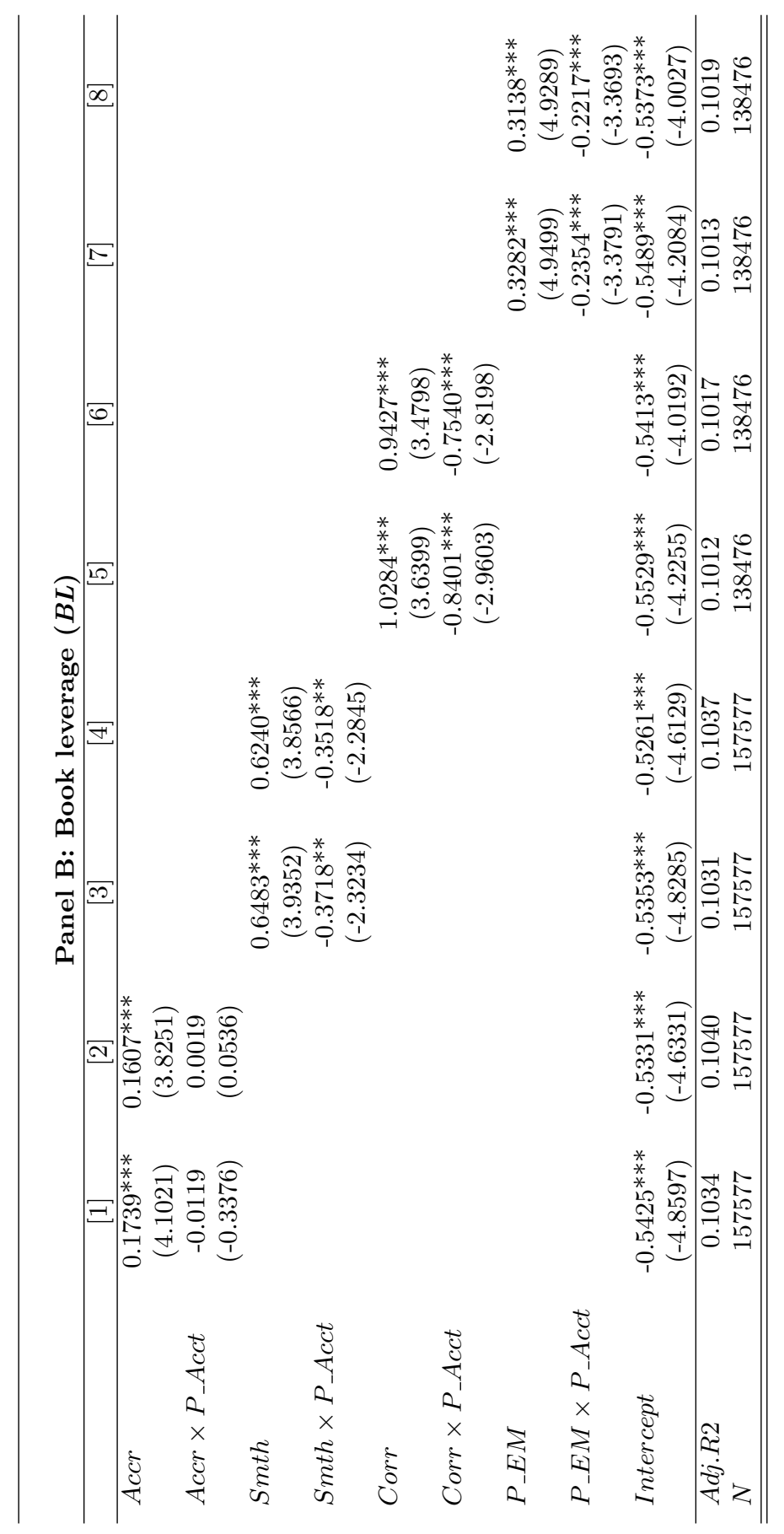




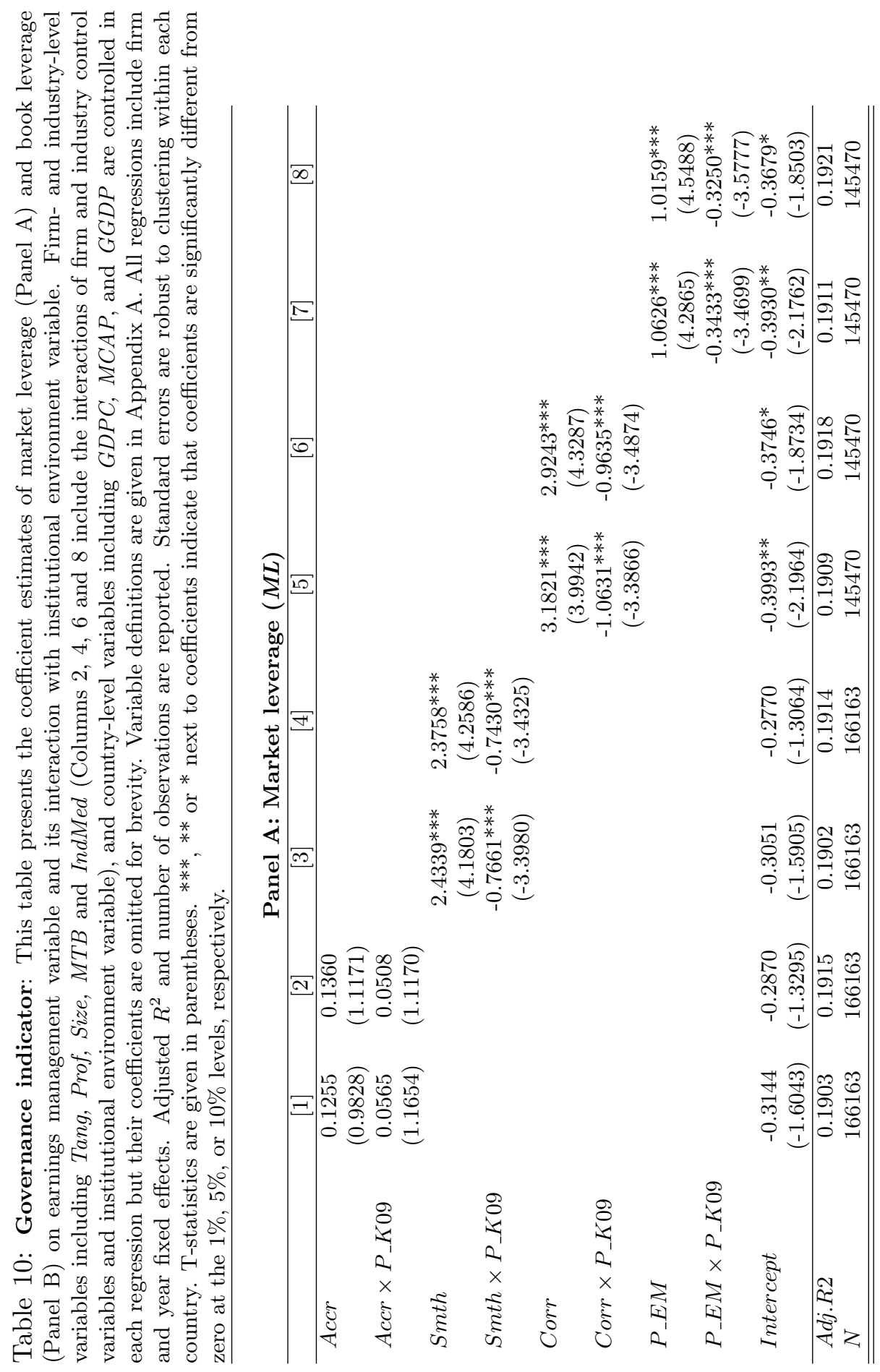




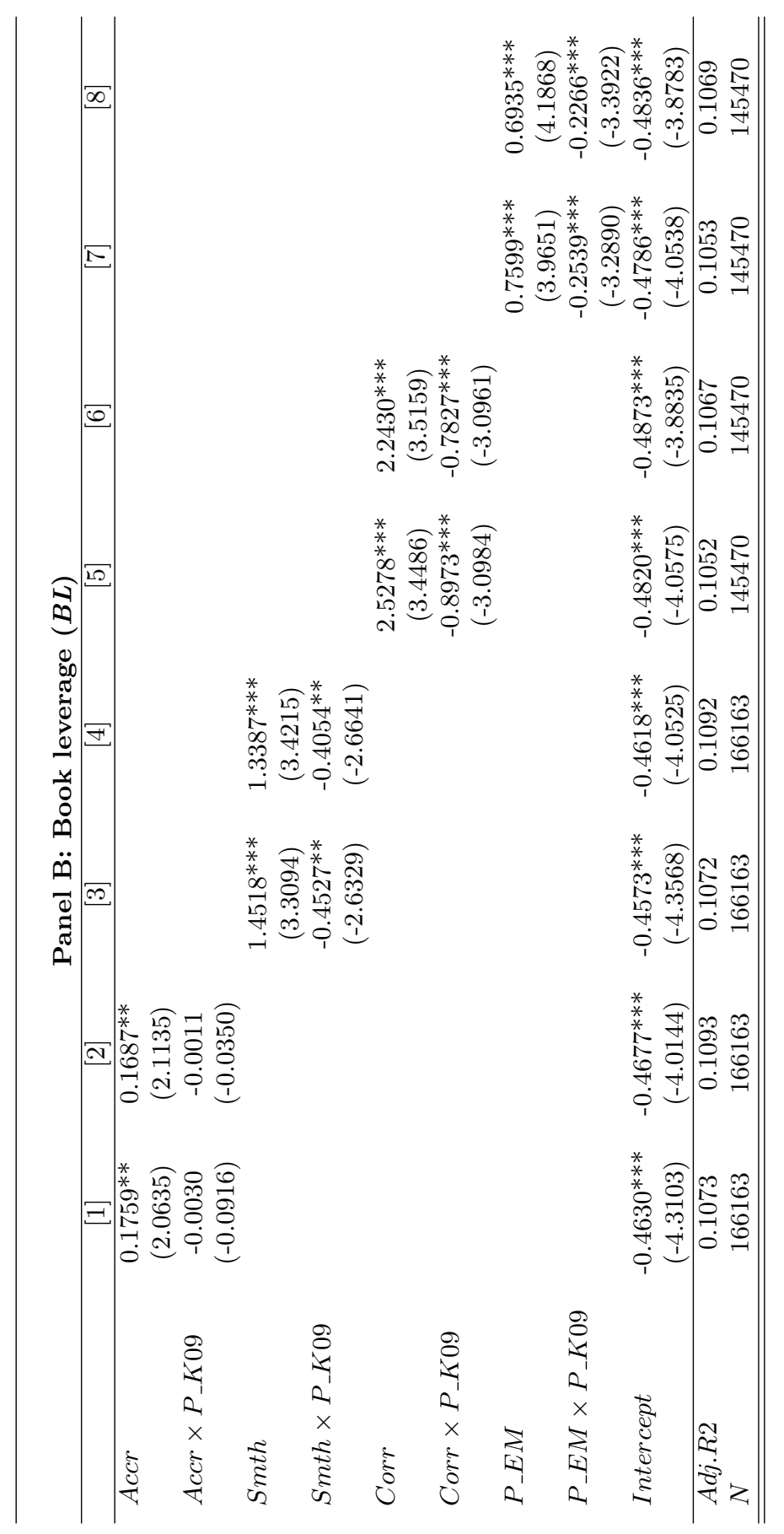




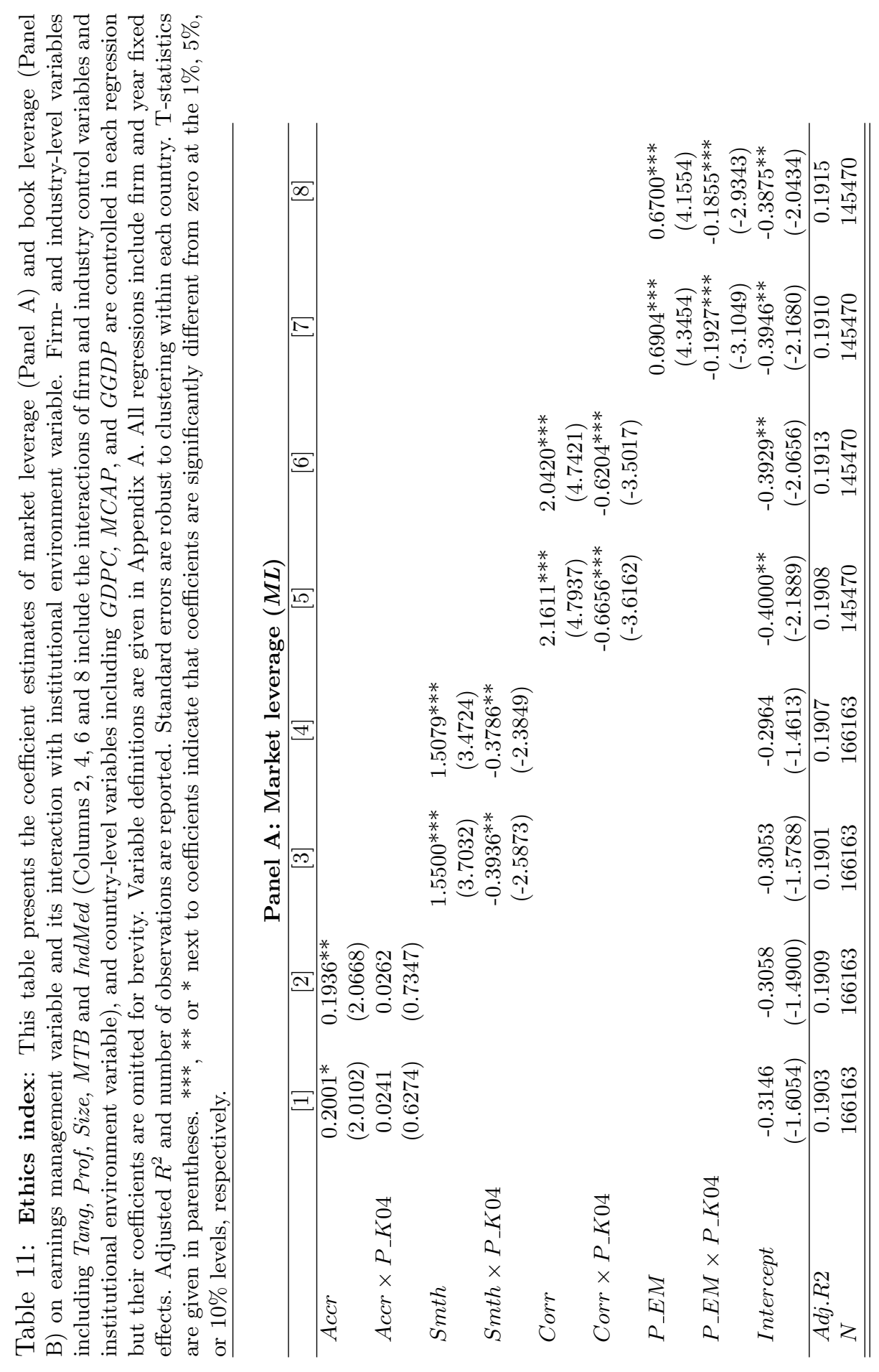




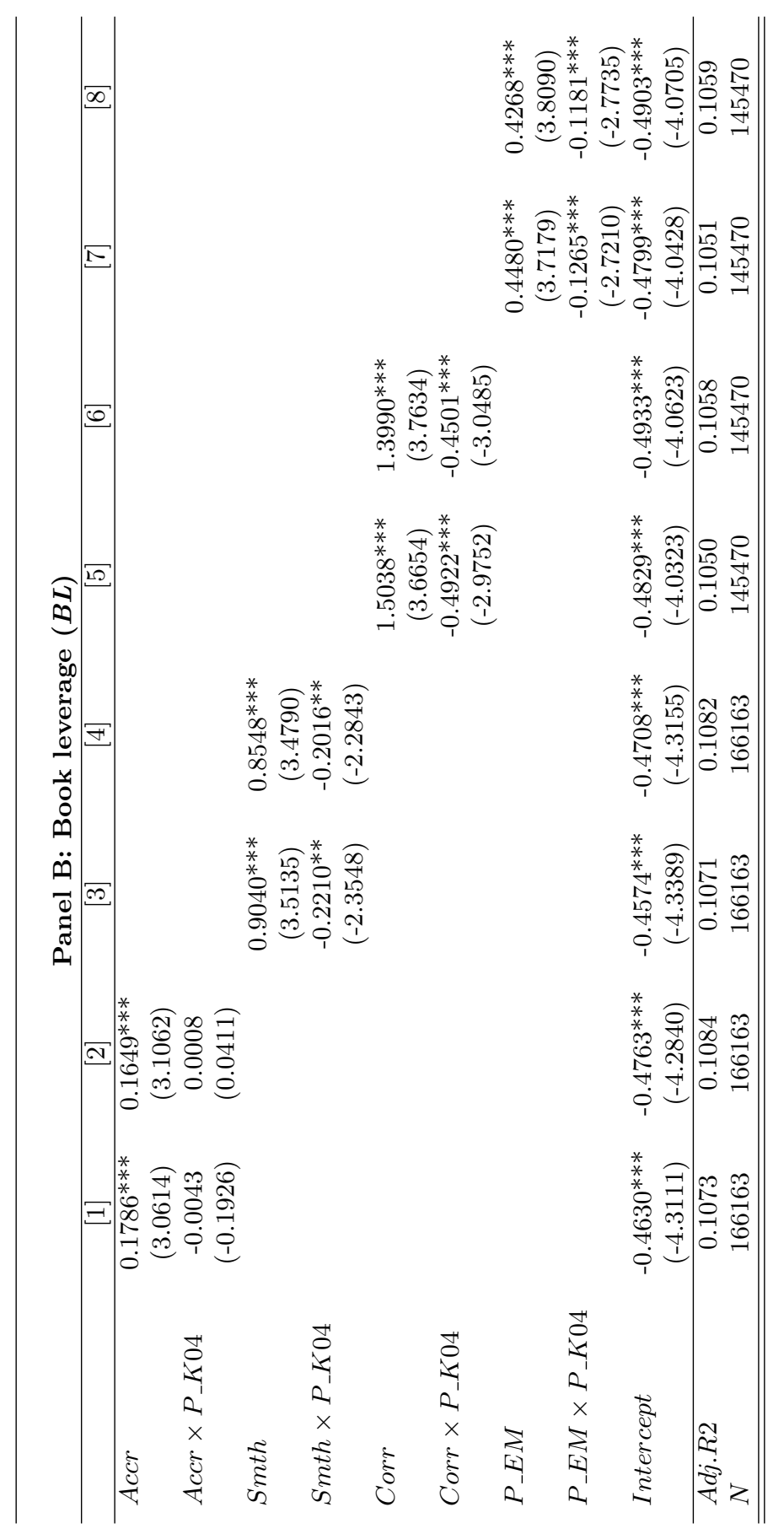




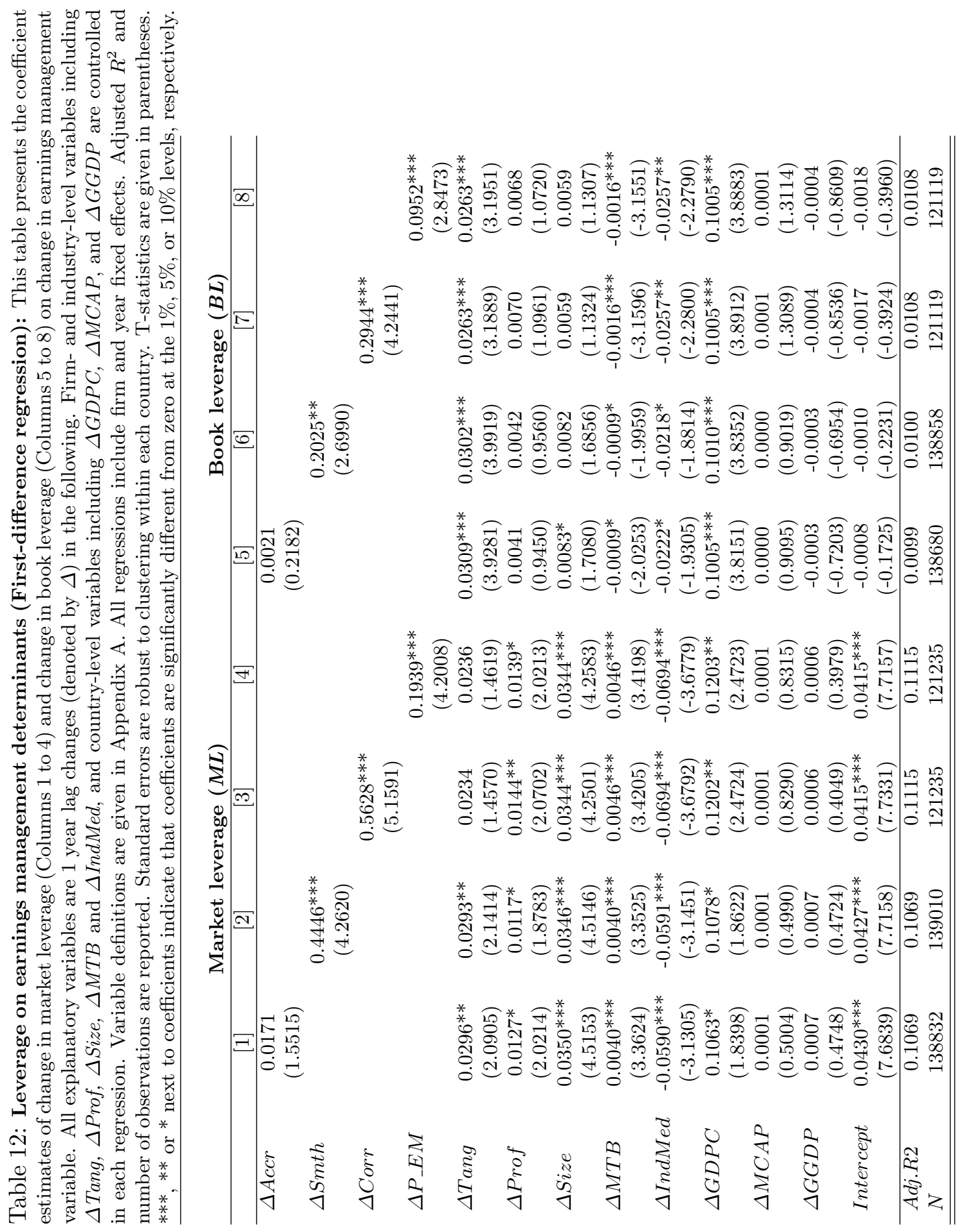




\section{A Appendix: Variable definitions}

\section{A.1 Firm and industry variables}

\section{A.1.1 Leverage ratios}

- Market leverage $(M L)$ : Book value of debt divided by market value of assets. Market value of assets is defined as the sum of book value of debt, market value of equity and book value of preferred stock, (Source: Worldscope)

- Book Leverage $(B L)$ : Book value of debt divided by book value of assets, (Source: Worldscope)

\section{A.1.2 Earnings management measures}

- Earnings discretion - magnitude of accruals $(A c c r): A^{A c c r} r_{j, i}=1 / 5$ $\sum_{t}^{t+4} \mid$ Accruals $_{j, i, t} / C F_{j, i, t} \mid$, Accruals $=(\Delta$ Assets $-\Delta$ Cash and equivalent $)-(\Delta$ Current liability $-\Delta$ Short term debt $-\Delta$ Income taxes payable) - Depreciation and amortization expense, Cash flow from operations $(C F)=$ Operating income - Accruals. When shortterm debt and taxes payable are not available for a firm, then their changes are assumed zero. All accounting variables are scaled by lagged total assets (A minimum of 3 years is required), (Source: Worldscope)

- Earnings smoothing - standard deviation $($ Smth): Smth $=-\sigma$ (Operating income) / $\sigma(C F)$ over the last 5 years, (A minimum of 3 years is required). (Source: Worldscope)

- Earnings smoothing - correlation $($ Corr $): \operatorname{Corr}=-\rho(\Delta A c c r, \Delta C F)$ over the last 5 years. (A minimum of 3 years is required), (Source: Worldscope)

- Earnings management - ( $\left.P_{-} E M\right)$ : The first principle component of Accr, Smth, and Corr, (Source: Worldscope) 


\section{A.1.3 Firm and industry control variables}

- Tangibility (Tang): Net property, plant and equipment dividend by book value of assets, (Source: Worldscope)

- Profitability (Prof): Earnings before interest, taxes, depreciation and amortization divided by book value assets, (Source: Worldscope)

- Size (Size): Natural Log of book value of assets which deflated to 2005 U.S. dollars by using the U.S. GDP deflator, (Source: Worldscope)

- Growth opportunity (MTB): Ratio of market value of assets to book value of assets, (Source: Worldscope)

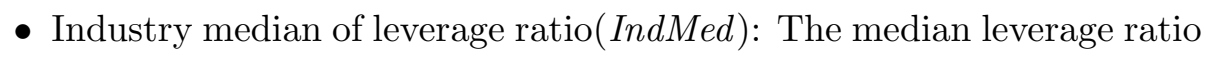
of an industry to which firms belong. Industry is classified based on Industry Classification Benchmark, (Source: Worldscope)

\section{A.2 Country control variables}

- GDP per capita $(G D P C)$ : Natural log of GDP per capita measured in U.S. dollar, (Source: World development indicator)

- Stock market capitalization to GDP $(M C A P)$ : Stock market capitalization scaled by GDP, (Source: World development indicator)

- GDP growth $(G G D P)$ : Annual GDP growth rate, (Source: World development indicator)

\section{A.3 Institutional environment variables}

- English common law (LegCom): Dummy variable equals 1 if a country adopts the common law system, zero otherwise, (Source: La Porta, Lopez-de-Silanes, Shleifer, and Vishny (1998))

- Enforcement (P_Enfor): The first principle component of EffJud, RulLaw, Corruption, RisExp and Repudiation. 
- Efficiency of judicial system (EffJud): Measures the efficiency and integrity of the countries' legal environment. The index is scaled from 0 (lowest efficiency) to 10 (highest efficiency), (Source: La Porta, Lopez-de-Silanes, Shleifer, and Vishny (1998))

- Rule of law (RulLaw): Measures the law and order tradition in the country. The index is scaled from 0 (lowest tradition) to 10 (highest tradition), (Source: La Porta, Lopez-de-Silanes, Shleifer, and Vishny (1998))

- Corruption (Corruption): Measures the corruption level of the government in the country. The index is scaled from 0 (lowest level of corruption) to 10 (highest level of corruption), (Source: La Porta, Lopez-de-Silanes, Shleifer, and Vishny (1998))

- Risk of expropriation (RisExp): Measures the risk of "outright conscation" or "forced nationalization". The index is scaled from 0 (highest risk) to 10 (lowest risk), (Source: La Porta, Lopez-deSilanes, Shleifer, and Vishny (1998))

- Repudiation of contracts by government (Repudiation): Measures the risk of a modification in a contract taking the form of a repudiation, postponement, or scaling down due to budget cutbacks, indigenization pressure, a change in government, or a change in government economic and social priorities. The index is scaled from 0 (highest risk) to 10 (lowest risk), (Source: La Porta, Lopez-de-Silanes, Shleifer, and Vishny (1998))

- Shareholder protection $\left(P_{-} S H\right)$ : The first principle component of $A n$ tiD and AntiSelf.

- Anti-director rights index (AntiD): An aggregated shareholder right index which including six dimensions. The index is formed by adding 1 when the country allows proxy the vote by mail; shareholders are not required to deposit their shares prior to the general shareholders' meeting; cumulative voting or proportional representation of minorities on the board of directors is allowed; 
an oppressed minorities mechanism is in place; the country requires the shareholder to hold at least 10 percent of share capital to call for an extraordinary shareholders' meeting; or shareholders have preemptive right that can be waived only by a shareholders' vote. This index is scaled from 0 (weakest shareholder protection) to 6 (strongest shareholder protection), (Source: La Porta, Lopez-de-Silanes, Shleifer, and Vishny (1998))

- Anti-self-dealing index (AntiSelf): Quality of shareholder right enforcement. It computed as the average of ex-ante and expost private control of self-dealing. Higher value indicate better quality of shareholder right enforcement of the country, (Source: Djankov, La Porta, Lopez-de-Silanes, and Shleifer (2008))

- Accounting information quality $\left(P_{-}\right.$Acct): The first principle component of AccStd90 and Audit.

- Accounting standards (AccStd90): Average inclusion or omission of the 90 accounting and non-accounting items by examining 1990 annual reports of the companies. Higher value indicate a more transparency information environment of the country. This items fall into seven categories (general information, income statements, balance sheets, fund of flow statements, accounting standards, stock data, and special items), (Source: La Porta, Lopez-de-Silanes, Shleifer, and Vishny (1998))

- Auditing practices (Audit): The percentage of firms in the country audited by the big 5 accounting firms. It equals $1,2,3$ or 4 if the percentage ranges between [0, 25\%], (25\%, 50\%], (50\%, $75 \%$ ] and (75\%, 100\%], (Source: Bushman, Piotroski, and Smith (2004))

- Governance indicator $\left(P_{\_} K 09\right)$ : The first principle component of 6 variables that measure various dimensions of governance. These variables include voice and accountability, political stability and absence of violence, government effectiveness, regulatory quality, rule of law, and 
control of corruption. Higher value indicate better institutional environment of the country, (Source: Kaufmann, Kraay, and Mastruzzi (2009))

- Ethics index (P_K04): The first principle component of 6 ethics and governance indices that measure various dimensions of corporate and public sector ethics and governance. These indices include corporate illegal corruption component, corporate legal corruption component, corporate ethics index, public sector ethics index, judicial/legal effectiveness index, and corporate governance index. Higher value indicate better institutional environment of the country, (Source: Kaufmann (2004)) 